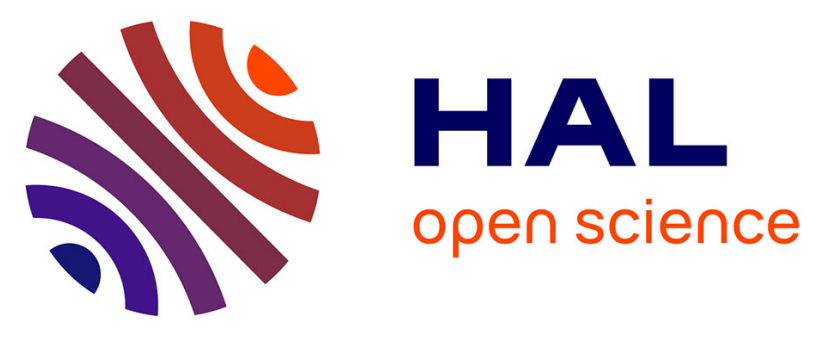

\title{
Relation between working properties and structural properties from 27Al, 29Si and 31P NMR and XRD of acid-based geopolymers from 25 to $1000^{\circ} \mathrm{C}$
}

Hélène Celerier, Jenny Jouin, Ameni Gharzouni, Virginie Mathivet, Isabel Sobrados, Nicolas Tessier-Doyen, Sylvie Rossignol

\section{To cite this version:}

Hélène Celerier, Jenny Jouin, Ameni Gharzouni, Virginie Mathivet, Isabel Sobrados, et al.. Relation between working properties and structural properties from 27Al, 29Si and 31P NMR and XRD of acid-based geopolymers from 25 to $1000^{\circ} \mathrm{C}$. Materials Chemistry and Physics, 2019, 228, pp.293-302. 10.1016/j.matchemphys.2019.02.049 . hal-02333610

\section{HAL Id: hal-02333610 \\ https://hal-unilim.archives-ouvertes.fr/hal-02333610}

Submitted on 26 Nov 2020

HAL is a multi-disciplinary open access archive for the deposit and dissemination of scientific research documents, whether they are published or not. The documents may come from teaching and research institutions in France or abroad, or from public or private research centers.
L'archive ouverte pluridisciplinaire HAL, est destinée au dépôt et à la diffusion de documents scientifiques de niveau recherche, publiés ou non, émanant des établissements d'enseignement et de recherche français ou étrangers, des laboratoires publics ou privés. 
Highlights: (maximum 85 characters, including spaces, per bullet point).

- Acid-based geopolymers display different processing-dependent working properties.

- Acid-based geopolymers are mostly composed of Al-O-P and $\mathrm{Si}(\mathrm{OH})_{4}$ networks.

- The quantities of Al-O-P and unreacted metakaolin govern the thermal resistance.

- The increase of the Young's modulus is related to a higher thermal resistance.

- Ordered structures and low amounts of physisobed water lead to water resistance.

Graphical Abstract Resistance of acid-based geopolymers with associated structural and working properties.

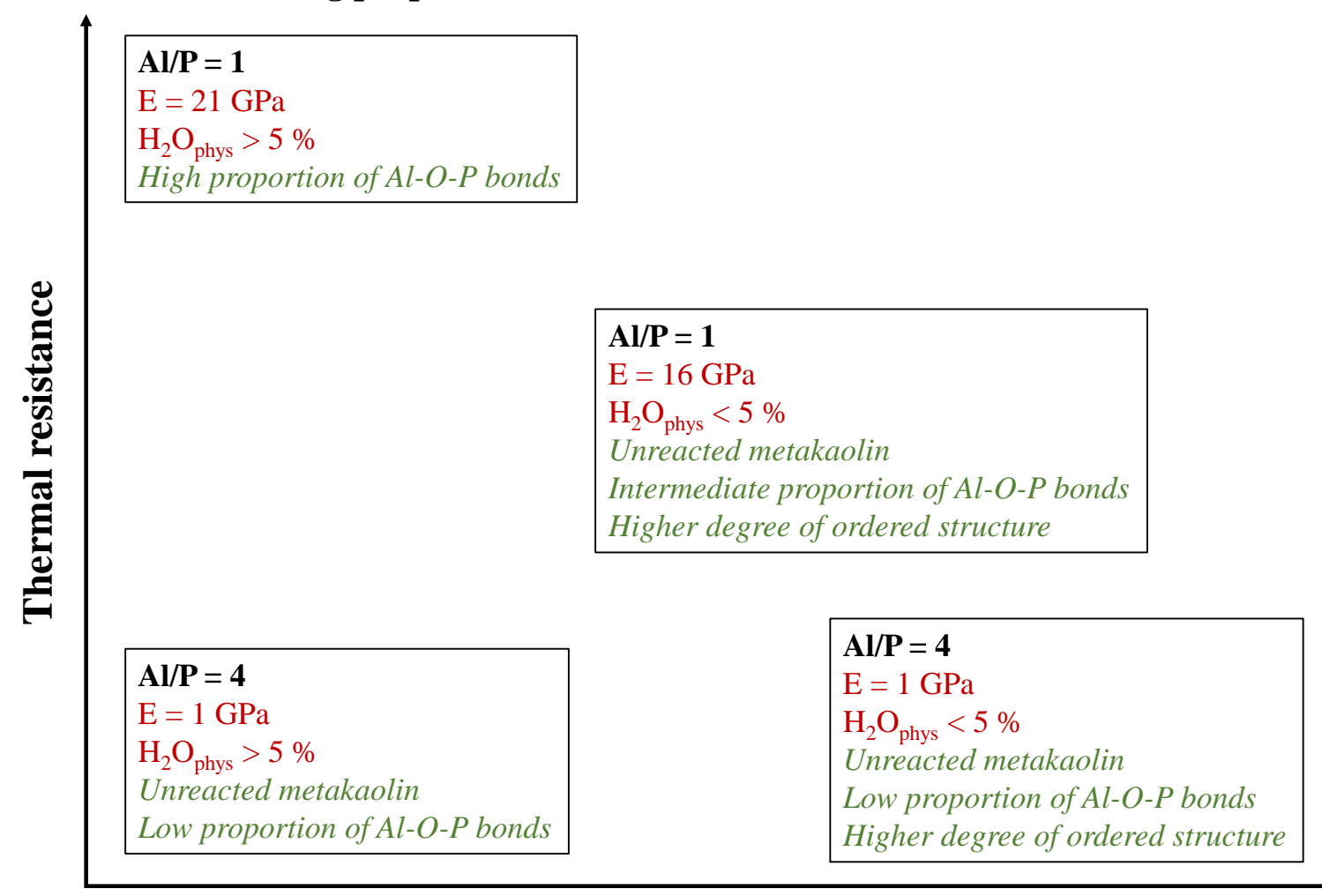

Water resistance 


\section{Supplementary material}

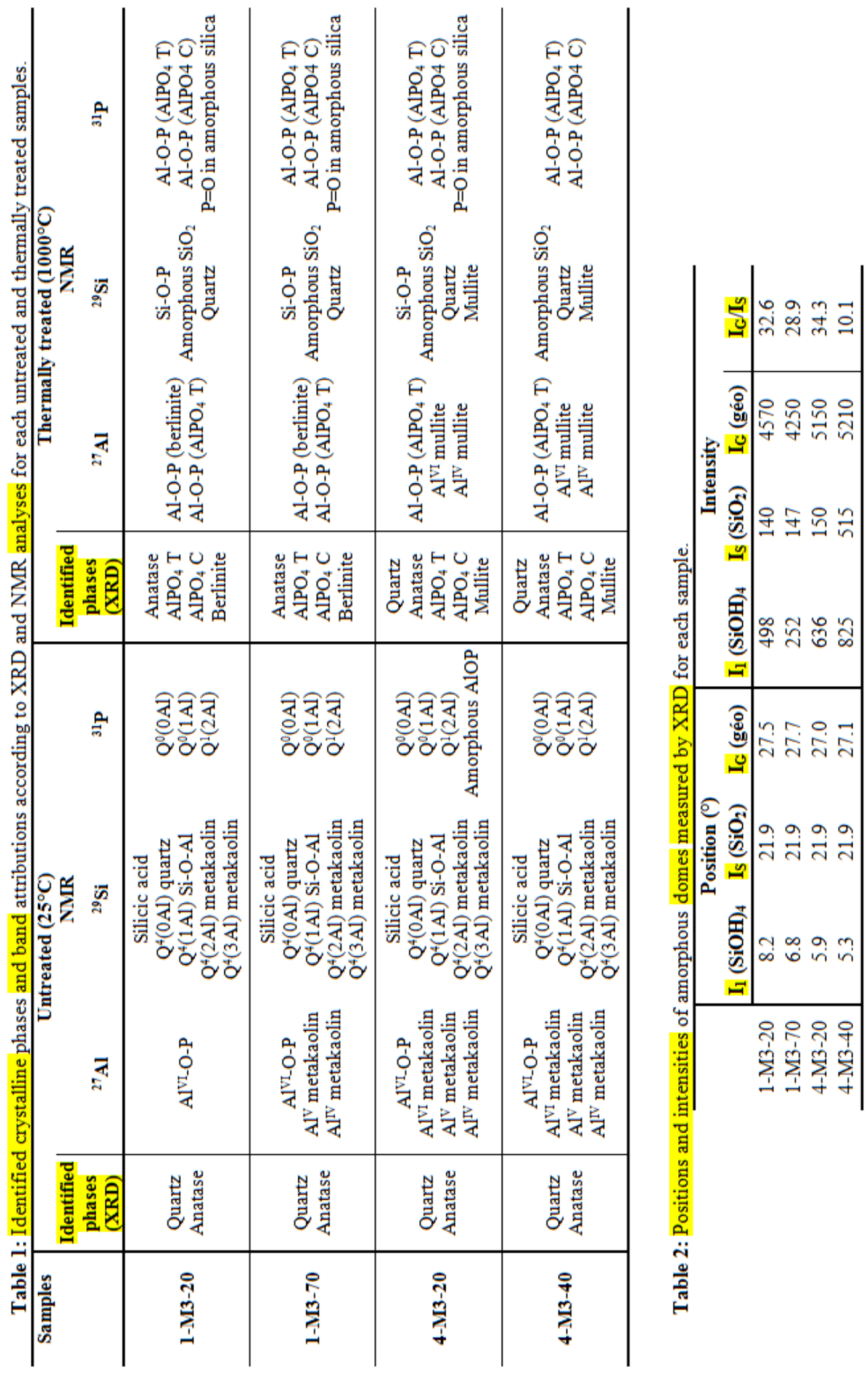




\title{
Relation between working properties and structural properties from ${ }^{27} \mathrm{Al}$, ${ }^{29} \mathrm{Si}$ and ${ }^{31} \mathrm{P}$ NMR and XRD of acid-based geopolymers from 25 to $1000^{\circ} \mathrm{C}$.
}

Hélène CELERIER ${ }^{1}$, Jenny JOUIN ${ }^{1}$, Ameni GHARZOUNI ${ }^{1}$, Virginie MATHIVET ${ }^{1,2}$, Isabel SOBRADOS ${ }^{3}$, Nicolas TESSIER-DOYEN ${ }^{1}$ and Sylvie ROSSIGNOL ${ }^{1, *}$

\begin{abstract}
${ }^{1}$ Institut de recherche sur les céramiques (IRCER), Centre européen de la céramique, 12 rue Atlantis, 87068 Limoges Cedex, France

${ }^{2}$ Office national d'études et de recherches aérospatiales (ONERA), 29 avenue de la Division Leclerc, 92320 Châtillon, France

${ }^{3}$ Instituto de ciencia de materiales de Madrid, Consejo superior de investigaciones científicas (CSIC), C/Sor Juana Inés de la Cruz, 3, 28049 Madrid, Spain

*Corresponding author: sylvie.rossignol@unilim.fr
\end{abstract}

\section{Abstract}

Acid-based geopolymers exhibit interesting properties, such as higher temperature resistance (up to $1450^{\circ} \mathrm{C}$ ) and better mechanical properties, as compared to alkali-based geopolymers. The aim of this work was to highlight the origin of water and thermal resistances of acid-based geopolymers, demonstrated in our previous study, by ${ }^{27} \mathrm{Al},{ }^{29} \mathrm{Si}$ and ${ }^{31} \mathrm{P} \mathrm{NMR}$ and XRD experiments. Different networks were indeed identified in consolidated materials, such as Al-O-P, Si-O-P, vitreous silica and Si-O-Al (only for $\mathrm{Al} / \mathrm{P}=4$, due to unreacted metakaolin) depending on processing conditions. The final properties are induced by the proportion of these networks which are controlled by the $\mathrm{Al} / \mathrm{P}$ ratio and the setting temperature. It was shown that a higher amount of Al-O-P bonds and the absence of unreacted metakaolin conduct to a thermally resistant sample. A more organized structure with a low proportion of $\mathrm{Q}^{0}(1 \mathrm{Al})$ and a preference for $\mathrm{Q}^{1}(2 \mathrm{Al})$, as seen by ${ }^{31} \mathrm{P} \mathrm{NMR}$, induces a great water resistance of geopolymers. After heating at $1000^{\circ} \mathrm{C}$, different $\mathrm{AlPO}_{4}$ polymorphs crystallize, as well as mullite in the case of $\mathrm{Al} / \mathrm{P}=4$.

Keywords: Metakaolin; Phosphoric acid; Thermal resistance; Water resistance; Amorphous network; NMR; XRD 


\section{Introduction}

Alkali-based geopolymers are well-known materials since many decades [i]. They result from the dissolution of an aluminosilicate source in an alkaline silicate solution [ii]. Recently, acid-based geopolymers are gaining interest from the scientific community for different applications, due to their promising properties. For instance, such materials exhibit a higher temperature resistance (up to $1450^{\circ} \mathrm{C}$ ) [iii] and greater mechanical properties [iv] than alkalibased geopolymers. On a structural point of view, acid-based geopolymers consist of threedimensional networks of $\mathrm{AlPO}_{4}$ and [Si-O-P]. It has indeed been reported that during synthesis, the dissolution of the aluminosilicate source in phosphoric acid leads to the release of $\mathrm{Al}^{3+}$ which react with $\mathrm{H}_{3} \mathrm{PO}_{4}$. The reaction between these entities later results in the formation of $\mathrm{AlPO}_{4}$ as observed by several authors [iv, v]. Moreover, the formation of [Si-O-P] bonds was also observed [vi]. Finally, the amount of available acid can affect the structure and the final properties of the material. On this subject, Douiri et al. [vii] demonstrated that the decrease of $\mathrm{Si} / \mathrm{P}$ ratio leads to a higher content of amorphous phase in the geopolymer structure due to a better dissolution of the precursors.

A previous work [viii] has shown that acid-based geopolymers may have different resistance properties (thermal or water resistance), governed both by the chemical composition and the setting temperature of materials $[i x, x] .$. However, their structure before and after thermal treatment was seldom exposed in the literature. A combination of spectroscopic techniques such as Fourier Transform Infrared spectroscopy (FTIR) [xi], Raman [xii] and Nuclear Magnetic Resonance (NMR) can be useful to study these materials due to the presence of amorphous phase. X-Ray Diffraction (XRD) patterns can also be used to study the amorphous humps and the crystalline phases formed after a heat treatment. Moreover, the publications dealing with amorphous materials such as glasses or gels can also be helpful to understand the structure and 
the different networks formed in acid-based geopolymers and will be developed in the next sections.

Firstly, in the case of the system $\mathrm{Al}_{2} \mathrm{O}_{3}-\mathrm{P}_{2} \mathrm{O}_{5}$, published works on $\mathrm{Al}_{2} \mathrm{O}_{3}$ doped phosphate glasses [xiii, xiv] proved the strong affinity between $\mathrm{P}^{5+}$ and $\mathrm{Al}^{3+}$ ions. The addition of $\mathrm{Al}^{3+}$ ions induces a modification of the phosphate glassy networks as demonstrated by NMR experiments. The original P-O-P bonds are indeed partly replaced by Al-O-P bonds by the insertion of $\mathrm{Al}^{\mathrm{VI}}$ into the network. This fact was evidenced by the formation of $\mathrm{Q}^{1}(1 \mathrm{Al})$, as observed on ${ }^{31} \mathrm{P}$ NMR spectra. Also, an heterogeneous distribution of $\mathrm{Al}^{3+}$ in the glassy network, causing a localized high concentration of $\mathrm{Al}^{3+}$, led to the formation of $\mathrm{Q}^{1}(2 \mathrm{Al})$. Moreover, it was shown that the addition of aluminum ions in phosphate glasses improves their chemical stability, and in particular, their water resistance. The dehydration and the temperature dependent phase transitions of $\mathrm{AlPO}_{4}$ based molecular sieves was studied by Varlec et al. [xv]. Based on an NMR study, they demonstrated that the hydrothermally stable $\mathrm{AlPO}_{4}-34$ contains hydrated aluminophosphate below $200^{\circ} \mathrm{C}$. The crystallization of triclinic phases from the amorphous aluminophosphate occurred during the synthesis, a greater occurrence being observed with an increase of the dwell time. Furthermore, XRD and NMR experiments conducted on $\mathrm{AlPO}_{4}-5$ molecular sieves [xvi] highlighted their transition from hexagonal to orthorhombic phases before calcination. The different phases observed (hexagonal, triclinic and orthorhombic) correspond to the different polymorphs of $\mathrm{AlPO}_{4}$ (assigned berlinite, phosphotridymite [xvii] and phosphocristobalite [xviii] respectively).

Then, several authors have studied the $\mathrm{SiO}_{2}-\mathrm{P}_{2} \mathrm{O}_{5}$ glass system, showing that the addition of $\mathrm{P}_{2} \mathrm{O}_{5}$ in silicate glasses results in the formation of Si-O-P bonds [xix, $\mathrm{xx}$ ]. PO43and $\mathrm{SiO}_{4}{ }^{4-}$ groups indeed copolymerize, leading to the easy incorporation of $\mathrm{P}^{5+}$ in the silicate network and the formation of the more covalent Si-O-P bonds [xxi]. However, the presence of the $\mathrm{P}=\mathrm{O}$ bond in the $\mathrm{PO}_{4}{ }^{3-}$ group limits the formation of the Si-O-P network. This effect leads 
to a partial conservation of the Si-O-Si bonds. Finally, Weeding et al. [xxii] studied the devitrification of a $\mathrm{SiO}_{2}-\mathrm{P}_{2} \mathrm{O}_{5}$ glass at 850,1000 and $1300^{\circ} \mathrm{C}$. Different crystalline compounds are formed in this system: $\mathrm{SiP}_{2} \mathrm{O}_{7}$ regardless of the temperature and $\mathrm{Si} 5 \mathrm{O}\left(\mathrm{PO}_{4}\right)_{6}$ at 850 and $1000^{\circ} \mathrm{C}$. An amorphous compound is also found in these materials at 850 and $1000^{\circ} \mathrm{C}$.

Concerning the $\mathrm{SiO}_{2}-\mathrm{Al}_{2} \mathrm{O}_{3}$ system, Zagrajczuk et al. [xxiii] presented the structure of their gel-derived materials. On XRD patterns, a broad hump, located between 20 and $30^{\circ}$, is characteristic of aluminosilicate amorphous materials. The main bonds present in the resulting structure are $\mathrm{Si}-\mathrm{O}-\mathrm{Si}, \mathrm{Al}-\mathrm{O}-\mathrm{Al}$ and $\mathrm{Si}-\mathrm{O}-\mathrm{Al}$. Si-OH silanol groups can also be present due to non-bridging oxygen atoms in the silica networks. After a heat treatment, the crystallization of mullite was observed, as it occurs in the solid state synthesis of $\mathrm{SiO}_{2}+\mathrm{Al}_{2} \mathrm{O}_{3}$ powders [xxiv]. The structure of this compound corresponds to a random distribution of tetrahedrally coordinated $\mathrm{Al}$ and Si.

Finally, glasses belonging to the $\mathrm{SiO}_{2}-\mathrm{Al}_{2} \mathrm{O}_{3}-\mathrm{P}_{2} \mathrm{O}_{5}$ system were also studied by many authors [xxv, xxvi, xxvii, xxviii] and the reported bonds are similar to the ones formed in the different binaries. The strong affinity between $\mathrm{Al}^{3+}$ and $\mathrm{P}^{5+}$ leads to the predominant formation of Al-O-P bonds, followed by Si-O-P bonds. Moreover, free amorphous silica is present in the glass and is characterized by the presence of $\mathrm{Si}-\mathrm{OH}$ and $-\mathrm{P}=\mathrm{O}$ units in its network. The $\mathrm{AlPO}_{4}$ units formed are randomly distributed in this silica network. It is also reported that, when $\mathrm{Al}$ is in excess in comparison to $\mathrm{P}$, it is associated with $\mathrm{Si}$ to form $\mathrm{Si}-\mathrm{O}-\mathrm{Al}$ bonds.

The structural evolution of acid-based geopolymers after thermal treatment is reported in literature. In all the cases, $\mathrm{AlPO}_{4}$ polymorphs were observed, although their temperature dependent distribution is different. Le-ping et al. [xxix] have shown that berlinite appears up to $900^{\circ} \mathrm{C}$, then cristobalite from $1150^{\circ} \mathrm{C}$ and finally mullite. Gualteri et al. [xxx] confirmed the presence of berlinite from $900^{\circ} \mathrm{C}$. Moreover, they observed tridymite and cristobalite type 
polymorphs of $\mathrm{AlPO}_{4}$ and mullite after a heat treatment at $1000^{\circ} \mathrm{C}$. From $1300^{\circ} \mathrm{C}$, no amorphous phase was detected [xxxi].

The present study is a structural investigation focused on four acid-based geopolymers exhibiting different resistance properties [viii]. This study, based on ${ }^{27} \mathrm{Al},{ }^{29} \mathrm{Si},{ }^{31} \mathrm{P}$ NMR and XRD experiments, aims to highlight the structural origin of thermal and water resistance of these materials.

\section{Materials and methods}

\subsection{Raw materials}

The aluminosilicate source was a kaolin supplied by Imerys (Limoges, France), with a $\mathrm{Si} / \mathrm{Al}$ ratio of 1 , which was calcined at $750^{\circ} \mathrm{C}$ for 4 hours at a heating rate of $5^{\circ} \mathrm{C} / \mathrm{min}$ to obtain the metakaolin noted M3. The characteristics and reactivity of this source were previously studied by Gharzouni et al. [xxxii]. The ACS grade solution of 85 wt. $\%$ of phosphoric acid was supplied by VWR (Radnor, USA) and corresponds to a concentration of 14.7 mol.L ${ }^{-1}$. The synthesis of acid-based geopolymer is described in Figure 1. Metakaolin M3 was mixed with diluted phosphoric acid solution in order to synthesize different compositions of geopolymers. Samples with two Al/P molar ratios (1 and 4) as well as three consolidation temperatures (20, 40 and $70{ }^{\circ} \mathrm{C}$ ) were prepared. The concentration of the diluted phosphoric acid solution varied for the two $\mathrm{Al} / \mathrm{P}$ ratio, i.e. $8.9 \mathrm{~mol} . \mathrm{L}^{-1}$ for $\mathrm{Al} / \mathrm{P}=1$ and $2.2 \mathrm{~mol} . \mathrm{L}^{-1}$ for $\mathrm{Al} / \mathrm{P}=4$. According to a previous work [viii], four samples, characteristics of different properties (thermal resistance (TR), water resistance (WR1 and WR2) and none resistance (N)), were chosen. These samples' names, properties and synthesis parameters are presented in the Table 1.

\subsection{Sample characterization}

The samples were calcined up to $1000^{\circ} \mathrm{C}$ in a furnace at $5^{\circ} \mathrm{C} \cdot \mathrm{min}^{-1}$ heating rate, followed by a two hours dwelling time and a natural cooling. 
The Young's modulus of each sample was measured by contact echography technique [xxxiii] on cylindrical samples (28 $\mathrm{mm}$ in diameter and $6 \mathrm{~mm}$ tall). Two couples of longitudinal and transversal transducers were used. Then the sample was placed between each couple of transducers in order to measure the time delay of the waves. From this delay, the speed of longitudinal and transversal waves and then the Young's modulus value were determined.

The amount of physisorbed water present in the samples after a 7 days immersion in water was determined both by differential thermal analysis (DTA) and thermogravimetric analysis (TGA) performed with an SDT Q600 apparatus from TA Instruments. The experiment was conducted up to $800^{\circ} \mathrm{C}$ at a heating rate of $5^{\circ} \mathrm{C} \cdot \mathrm{min}^{-1}$, in an atmosphere of flowing dry air $\left(100 \mathrm{~mL} \cdot \mathrm{min}^{-1}\right)$ in platinum crucibles. The temperature signals were measured with $\mathrm{Pt} / \mathrm{Pt}-$ $10 \% \mathrm{Rh}$ thermocouples. The samples were previously dryed at $40{ }^{\circ} \mathrm{C}$ during $12 \mathrm{~h}$ and then crushed in an agate mortar. The measured weight loss corresponds to the fist mass loss of the sample and was measured from $20^{\circ} \mathrm{C}$ to $70^{\circ} \mathrm{C}$.

A Bruker AVANCE-400 spectrometer operating at $79.49 \mathrm{MHz}\left({ }^{29} \mathrm{Si}\right.$ signal), 104.26 $\mathrm{MHz}\left({ }^{27} \mathrm{Al}\right.$ signal) and $161.98 \mathrm{MHz}\left({ }^{31} \mathrm{P}\right.$ signal $)$ was used for high resolution MAS-NMR experiments at room temperature. NMR spectra were recorded after $\pi / 2$ pulse irradiation $(2 \mu \mathrm{s})$ using a $10 \mathrm{kHz}$ filter to improve the signal/noise ratio. 120 scans were collected for each crushed sample. The time between acquisitions was set to $10 \mathrm{~s}$ to minimize saturation effects. DMFIT software was used to obtain the relative area of components. Different models employed were "quad $1^{\text {st }}$ model", "Gaussian/Lorentzian distribution" and "CSA model" for ${ }^{27} \mathrm{Al},{ }^{29} \mathrm{Si}$ and ${ }^{31} \mathrm{P}$ NMR data respectively. Estimated errors for chemical shifts and relative area are of $0.2 \mathrm{ppm}$ and $2 \%$ respectively.

The crushed samples were characterized by X-ray diffraction (XRD) on a Bruker D8 Advance diffractometer using $\mathrm{CuK} \alpha$ radiation. The data were collected over the $2 \theta$ angular range of $5-60^{\circ}$ with a step size of $0.02^{\circ}$ and an equivalent measured time per step of $50 \mathrm{~s}$. The 
crystalline phases were identified from the experimental patterns using the powder diffraction file (PDF) database of the International Center for Diffraction Data. Peakoc software [xxxiv] was used to obtain the positions and intensities of the amorphous contributions observed. The refinement was performed from 5 to $60^{\circ}$ using a Voigt function that takes into account $\mathrm{K} \alpha_{1}$ and $\mathrm{K} \alpha_{2}$ wavelengths. The continuous background was fitted by a $2^{\text {nd }}$ order polynomial.

\section{Results}

\subsection{Working properties}

Young's modulus of the consolidated samples were measured for the four different resistances, as defined in [viii], namely TR, WR1, WR2 and N. As seen in Table 2, the Young's modulus decreases, both with the increase of the setting temperature and the Al/P ratio. Moreover, 1-M3-20 sample, which is the only thermal resistant sample, possesses the highest Young's modulus with a value of $21 \mathrm{GPa}$. This is probably due to the presence of stronger bonds in the material, which is in agreement with the thermal resistance of the sample.

The amount of physisorbed water present in the samples after the water resistance test was measured using thermal analysis. As an example, Figure 2 represents the weight loss of the 1-M3-20 sample. These losses, measured between $20^{\circ} \mathrm{C}$ and $70^{\circ} \mathrm{C}$, are reported in Table 2 . Although they are quite close, they are slightly different for each sample, with the highest value of $5.7 \%$ for $4-\mathrm{M} 3-40$ and the lowest of 3.8\% for 4-M3-20. Moreover, 1-M3-70 and 4-M3-20 are water resistant. This means that water resistant samples absorb less than $5 \%$ of water during a prolonged immersion.

\subsection{Structural properties - NMR}

\section{Consolidated geopolymers}


Structural informations about raw samples were obtained by MAS-NMR experiments. The measured spectra, showing the identified contributions, are given in Figure 3 and all the deconvolution data are gathered in the Table 3.

As a reminder, NMR of metakaolin M3, which is also given in Table 3, has already been studied by Gharzouni et al. [xxxii] concerning ${ }^{27} \mathrm{Al}$ and Autef et al. $[\mathrm{xxxv}]$ for ${ }^{29} \mathrm{Si}$. In the case of ${ }^{27} \mathrm{Al}$ spectra, three contributions were identified at 56, 30 and $1 \mathrm{ppm}$, corresponding to $\mathrm{Al}^{\mathrm{IV}}$, $\mathrm{Al}^{\mathrm{V}}$ and $\mathrm{Al}^{\mathrm{VI}}$ in the metakaolin respectively. Silicium entities observed at -96 and $-107 \mathrm{ppm}$ could be attributed to $\mathrm{Q}^{4}(2 \mathrm{Al})$ of $\mathrm{Si}-\mathrm{O}-\mathrm{Al}$ bonds in metakaolin and $\mathrm{Q}^{4}(0 \mathrm{Al})$ of quartz.

As shown in Figure 3, whatever the geopolymer, ${ }^{27} \mathrm{Al},{ }^{29} \mathrm{Si}$ and ${ }^{31} \mathrm{P}$ MAS-NMR spectra present relatively broad peaks, revealing a disordered structure. Firstly, on ${ }^{27} \mathrm{Al}$ spectra of 1 M3-20 (TR) sample (Figure 3A), the signal includes two contributions at -13 and $-22 \mathrm{ppm}$ corresponding to $\mathrm{Al}^{\mathrm{VI}}$ of Al-O-P bonding [xxvi, xxxvi]. The relative area of these two contributions are quite similar (58 and $42 \%$ respectively). When the consolidation temperature is higher, i.e. $70^{\circ} \mathrm{C}$ (1-M3-70 (WR1) sample), the same contributions are visible but the relative area of the first peak varies from $58 \%$ to $49 \%$, the second one remaining constant (Table 3 ). Moreover, two additional contributions are observed at 43 and $28 \mathrm{ppm}$ which can be attributed to $\mathrm{Al}^{\mathrm{IV}}$ of $\mathrm{Al}(\mathrm{OP})_{4}$ entities [xxxvi, xxxvii, xxxviii] and $\mathrm{Al}^{\mathrm{V}}$ of metakaolin [ii] respectively. When the A1/P ratio increases (4M3-20 (WR2) and 4-M3-40 (N) samples), the contributions at -10 and -23 ppm are still observed. However, the area of the first one decreases while the second remains similar, as compared to samples with $\mathrm{Al} / \mathrm{P}=1$. The three other indentified contributions for 4-M3-20 (WR2), at 50, 28 and 9 ppm, correspond to $\mathrm{Al}^{\mathrm{IV}}, \mathrm{Al}^{\mathrm{V}}$ and $\mathrm{Al}^{\mathrm{VI}}$ of metakaolin respectively [ii, 36]. In the case of $\mathrm{Al} / \mathrm{P}=4$, the metakaolin is in excess in the reactive mixture and its dissolution is incomplete [ii]. Therefore these contributions coincide with the quantity of unreacted metakaolin in the sample. 4-M3-40 (N) sample exhibits the same contributions as 
4-M3-20 (WR2) sample, except for the $\mathrm{Al}^{\mathrm{VI}}$ which disappears. This trend is the consequence of a better dissolution of the metakaolin at this temperature.

In the case of ${ }^{29} \mathrm{Si}$ MAS-NMR spectra (Figure 3B), five contributions were identified for all samples at $-90,-94,-102,-106$ and $-111 \mathrm{ppm}$, and attributed to $\mathrm{Q}^{4}(3 \mathrm{Al}), \mathrm{Q}^{4}(2 \mathrm{Al})$ and $\mathrm{Q}^{4}(1 \mathrm{Al})$ of metakaolin, $\mathrm{Q}^{4}(0 \mathrm{Al})$ of quartz [v, vi, xxxvi] and silicic acid [xxxix] respectively. 1M3-20 (TR) mostly contains silicic acid. With an increase of the consolidation temperature, the relative area of each contribution slightly evolves, as seen for 1-M3-70 (WR1) (Table 3). For 4-M3-20 (WR2) sample, the curve areas vary significantly and $\mathrm{Q}^{4}(1 \mathrm{Al})$ becomes the major contribution with $36 \%$. Silicic acid is again the major contribution in the case of 4-M3-40 (N) sample. This can be explained by the better dissolution of the metakaolin due to the thermal activation already supposed from ${ }^{27} \mathrm{Al}$ measurement. Indeed, similarly to the alkali activation [ii], the increase of the setting temperature promotes the dissolution of metakaolin as well as the polycondensation reactions. This fact also explains the absence of $\mathrm{Al}^{\mathrm{VI}}$ of metakaolin in this sample.

Finally, whatever the $\mathrm{Al} / \mathrm{P}$ ratio, the same environments were identified on ${ }^{31} \mathrm{P}$ spectra (Figure 3C). The three contributions at $-1,-7$ and $-16 \mathrm{ppm}$ correspond to $\mathrm{Q}^{1}(0 \mathrm{Al}), \mathrm{Q}^{1}(1 \mathrm{Al})$ and $\mathrm{Q}^{1}(2 \mathrm{Al})$, respectively [xl, $\left.\mathrm{xli}\right]$. For all the samples, the predominant entity, with an intensity value of at least $75 \%$, is $\mathrm{Q}^{1}(2 \mathrm{Al})$, which confirms the presence of Al-O-P bonds as observed in the ${ }^{27} \mathrm{Al}$ spectra. The minor contribution is $\mathrm{Q}^{1}(0 \mathrm{Al})$ (less than $4 \%$ ) which is in agreement with the presence of a low quantity of unreacted $\mathrm{PO}_{4}{ }^{3-}$ tetrahedra from phosphoric acid. This fact confirms that almost all of the phosphoric acid reacts with the metakaolin. 1-M3-20 (TR) sample exhibits $80 \%$ of the main contribution $\left(\mathrm{Q}^{1}(2 \mathrm{Al})\right.$ ) (Table 2). When the setting temperature increases (1-M3-70 (WR1)), the percentage of the curve area of $\mathrm{Q}^{1}(2 \mathrm{Al})$ increases (90\%) at the expense of those from $\mathrm{Q}^{1}(1 \mathrm{Al})$ and $\mathrm{Q}^{1}(0 \mathrm{Al})$. In the case of 4-M3-20 (WR2), a new contribution at $-11 \mathrm{ppm}(9 \%)$ corresponding to amorphous Al-O-P [xxxviii] is visible. 
Moreover, the amount of the contribution corresponding to $\mathrm{Q}^{1}(2 \mathrm{Al})$ decreases when the $\mathrm{Al} / \mathrm{P}$ ratio increases (around 77\%). For 4-M3-40 (N) sample, the contribution of amorphous Al-O-P disappears with the increase of consolidation temperature. This leads to a higher percentage of the curve area of the contribution of $\mathrm{Q}^{1}(1 \mathrm{Al})$ from 13 to $19 \%$.

To summarize these results, a graphic representation is given in Figure 4, which represents the relative areas of the different contributions, plotted as a function of the chemical shifts for the species ${ }^{31} \mathrm{P},{ }^{29} \mathrm{Si}$ and ${ }^{27} \mathrm{Al}$, for all the samples. It was shown that an increase in the ratio $\mathrm{Al} / \mathrm{P}$ tends to enhance the contributions due to metakaolin, as it can be seen by the presence of these contributions in Figure 4A. Indeed, samples synthetized with $\mathrm{A} 1 / \mathrm{P}=4$ contain an excess of metakaolin, reaching its dissolution limit. This induces, in Figure 4B, the presence of less silicic acid and $\mathrm{Q}^{4}(1 \mathrm{Al})$ corresponding respectively to silicon bonded to surface $\mathrm{OH}\left(\mathrm{Si}(\mathrm{OH})_{4}\right)$ and to Si-O-Al bonds. We can note that these bonds are formed due to the affinity of the released $\mathrm{Al}$ and the silicon coming from the de-aluminated metakaolin. Concerning, the reaction between $\mathrm{Al}$ and $\mathrm{P}$, the contributions of $\mathrm{Al}^{\mathrm{VI}}-\mathrm{O}-\mathrm{P}$ bonds are dominant for $\mathrm{Al} / \mathrm{P}$ of 1 , which confirms the strong affinity of these species. The presence of these bonds allows to assume the formation of $\mathrm{AlPO}_{4}$ crystals during a high temperature thermal treatment. The increase of the setting temperature for the samples with $\mathrm{Al} / \mathrm{P}=1$ causes a decrease of $\mathrm{Al}^{\mathrm{VI}}-\mathrm{O}-\mathrm{P}$ replaced by $\mathrm{Al}^{\mathrm{IV}}$. This could lead to the formation, of different types of $\mathrm{AlPO}_{4}$ crystals during the calcination, this point will be developed later. Moreover, $\mathrm{Al}^{\mathrm{V}}$ of metakaolin are not fully consumed for this sample. The increase of the amount of silicic acid is explained by the decrease of Si-O-Al bonds $\left(\mathrm{Q}^{4}(1 \mathrm{Al})\right)$ due to a lower quantity of free aluminum able to form these bonds. In the case of $\mathrm{Al} / \mathrm{P}=4$, the increase of the setting temperature does not affect the quantity of $\mathrm{Al}^{\mathrm{VI}}-\mathrm{O}-\mathrm{P}$. However, the $\mathrm{Al}^{\mathrm{VI}}$ from metakaolin disappears (Figure 4A). This absence causes a decrease of Al-O-Si bonds from $\mathrm{Q}^{4}(1 \mathrm{Al})$, leading to more silicon being available to react with surface $\mathrm{OH}$ to form silicic acid. 


\section{Geopolymers thermally treated at $1000^{\circ} \mathrm{C}$}

After a calcination at $1000^{\circ} \mathrm{C}$ (Figure 2.b), the NMR peaks of the samples, represented in Figure 5, are narrower than the ones measured on consolidated samples, indicating a higher degree of structural order [xlii]. ${ }^{27} \mathrm{Al}$ MAS-NMR spectra (Figure 5A) show that 1-M3-20 (TR) and 1-M3-70 (WR1) samples exhibits a unique contribution at $39 \mathrm{ppm}$ corresponding to $\mathrm{AlPO}_{4}$ entities of berlinite [xxvi] and phosphotridymite [xliii]. With a ratio $\mathrm{Al} / \mathrm{P}=4$, two other contributions at 57 and $1 \mathrm{ppm}$, corresponding to $\mathrm{Al}^{\mathrm{IV}}$ and $\mathrm{Al}^{\mathrm{VI}}$ of mullite respectively, were identified [xxiv]. This mullite crystallized from the unreacted metakaolin present in these samples. On ${ }^{29} \mathrm{Si}$ spectra (Figure 5B), three contributions at $-104,-114$ and $-124 \mathrm{ppm}$ were observed for 1-M3-20 (TR). These contributions correspond to quartz impurity in the raw metakaolin M3, disordered free silica [xliv, xlv] and Si-O-P bonds [xxvi, xlvi] respectively with a majority of free silica (97\%) (see the deconvoluted values in Table 4). The same contributions can be seen for 1-M3-70 (WR1) with quite similar proportions. In addition to these contributions, 4-M3-20 (WR1) presents three additional ones at -86, -89 and -94 ppm, which all correspond to mullite [xliv, xlv]. When the setting temperature increases for this composition (4-M3-40), the contribution of Si-O-P bonds disappears, while contributions corresponding to free silica (-110 and -115 ppm), quartz (-99 ppm) and mullite (-89 and $-96 \mathrm{ppm})$ are still present. Finally, in the case of ${ }^{31} \mathrm{P}$ MAS-NMR spectra (Figure 5C), the three contributions at $-28,-31$ and -38 ppm for 1-M3-20 (TR) sample correspond to $\mathrm{AlPO}_{4}$ entities, namely phosphotridymite [xliii, xlvii] and phosphocristobalite [xlviii] and $-\mathrm{P}=\mathrm{O}$ in vitreous silica [xxviii]. Others samples contain also the same contributions except 4-M3-40 for which the contribution of $-\mathrm{P}=\mathrm{O}$ in vitreous silica was not observed.

As for consolidated materials, a graphic representation is given in Figure 6 to summarize these results. It represents the relative areas of the different contributions, plotted as a function of the chemical shifts for the species ${ }^{31} \mathrm{P},{ }^{29} \mathrm{Si}$ and ${ }^{27} \mathrm{Al}$, for all the samples. From these 
informations, it can be concluded that regardless the setting temperature for $A 1 / P=1$, all aluminum reacts with the phosphorus ions to form $\mathrm{AlPO}_{4}$ polymorphs (berlinite and phosphotridymite, see Figure 6A). Concerning silicium ions, Figure 6B, the predominant entity is free amorphous silica, which is formed from silicic acid observed in the consolidated samples before calcination. Indeed, silicic acid is completely and irreversibly deshydroxylated from $900^{\circ} \mathrm{C}$ [xlix]. Therefore, the identified Si-O-P bonds are formed from unreacted $\mathrm{PO}_{4}{ }^{3-}$ and unreacted silicon. When $\mathrm{Al} / \mathrm{P}$ increases from 1 to 4 , the same $\mathrm{AlPO}_{4}$ polymorphs and free amorphous silica can be observed. $\mathrm{Al} / \mathrm{P}=4$ consolidated samples also contained an excess unreacted metakaolin leading to an excess of aluminum species which had not reacted. This aluminum combined to silicon forms mullite at high temperature. At a setting temperature of $40^{\circ} \mathrm{C}$, Si-O-P bonds and $\mathrm{P}=\mathrm{O}$ in amorphous silica are not formed because the increase of setting temperature allowed a better dissolution of metakaolin as explained previously. All phosphorous thus reacts with aluminum, leaving no phosphorous to react with silicon.

\subsection{Structural properties - XRD}

The XRD patterns of the samples before and after calcination at $1000^{\circ} \mathrm{C}$ are shown in the Figure 4. Before calcination, all the diagrams present some broad amorphous humps, with peaks corresponding to crystallized anatase and quartz impurities. These crystalline phases are already present in the raw metakaolin [ii, 1]. The amorphous contributions, located at around $8^{\circ}, 22^{\circ}$ and $27^{\circ}$, correspond to silicic acid [li], amorphous silica [lii] and geopolymeric networks [liii] respectively, as observed in NMR. Regardless of the composition, the positions at 22 and $27^{\circ}$ do not vary. However, the position of the silicic acid contribution, which is very sensitive to the amount of water, shifts towards lower angles when the setting temperature and/or the Al/P ratio increase. Moreover, for 4-M3-20 (WR1), another hump was detected at $41^{\circ}$ and could be assigned to an amorphous Al-O-P network according to NMR results. 
After a heat-treatment at $1000^{\circ} \mathrm{C}$, the samples are mostly crystallized. However, samples with $\mathrm{Al} / \mathrm{P}=1$ are better crystallized, and exhibit different $\mathrm{AlPO}_{4}$ polymorphs such as berlinite (hexagonal), phosphotridymite (triclinic) and phosphocristobalite (orthorhombic). Anatase originating from the raw metakaolin is also observed. In these samples, phosphotridymite phase predominates over the berlinite. Moreover, there are more $\mathrm{AlPO}_{4}$ phosphotridymite polymorphs in 1-M3-20 (TR) than in 1-M3-70 (WR1). The calcined samples synthetized with ratio Al/P = 4 (4-M3-20 (WR2) and 4-M3-40 (N)) are not so well crystallized and exhibit broader peaks. Only a few peaks from $\mathrm{AlPO}_{4}$ orthorhombic and triclinic polymorphs were observed. The quartz and anatase which were present in the raw metakaolin are clearly visible. Finally, the presence of an excess of unreacted metakaolin leads to the formation of poorly crystallized mullite.

\section{Discussion}

\subsection{Structure}

In this study, it was observed that with an $\mathrm{Al} / \mathrm{P}$ ratio of 1 , an $\mathrm{Al}-\mathrm{O}-\mathrm{P}$ network combined with $\mathrm{Si}(\mathrm{OH})_{4}$ is formed regardless the setting temperature. The formation of $\mathrm{Si}(\mathrm{OH})_{4}$ is however favored by the increase of the setting temperature. When the Al/P ratio increases to 4, two main networks are formed ( $\mathrm{Si}-\mathrm{O}-\mathrm{Al}$ and $\mathrm{Al}-\mathrm{O}-\mathrm{P})$. With the increase of the setting temperature, the proportion of Al-O-P increases and different secondary networks are observed such as amorphous silica, $\mathrm{Si}-\mathrm{O}-\mathrm{P}$ and $-\mathrm{P}=\mathrm{O}$ in amorphous silica.

The amount of Al-O-P bonds decreases when an increase of the setting temperature occurs in the case of an $\mathrm{Al} / \mathrm{P}$ ratio of 1 . As the temperature increases, consolidation-induced thermal agitation indeed makes the material more unstable. The reactions are inhibited and the species are fixed such as observed in glasses [liv].These facts are in agreement with the crystallization of different $\mathrm{AlPO}_{4}$ polymorphs and the presence of free amorphous silica 
observed by XRD. Moreover, the amount of phosphotridymite decreases significantly when the setting temperature increases with $\mathrm{Al} / \mathrm{P}=1$. With a ratio $\mathrm{Al} / \mathrm{P}$ of 4 , the excess of metakaolin leads to a higher dispersion of the reactive species. In this case, the increase of the setting temperature also favors the dissolution of the metakaolin. Thus, more free-silica is dispersed in the geopolymeric network. With an Al/P ratio of 1 , XRD patterns confirms the tendency as there are slightly less geopolymeric contribution as compared to silica's one. For $\mathrm{Al} / \mathrm{P}=4$, the

presence of unreacted metakaolin changes $\frac{\mathrm{I}_{G}}{\mathrm{I}_{S}}$, leaving some free aluminum in the system which cannot react with phosphorous. Consequently, an increase of the setting temperature leads to a drastic decrease of the intensity of the geopolymer's contribution to the benefit of silicon, which can be the reason of the poor resistance of this sample.

\subsection{Working properties and resistances}

The resistance properties of the samples were considered both with the working properties (Young's modulus of untreated samples and amount of physisorbed water of saturated samples) and the local environment of the samples as characterized using NMR. These informations are reported in the Figure 9.

Firstly, in the case of the thermal resistance (Figure 9A) the amount of Al-O-P bonds formed, of unreacted metakaolin in the consolidated samples and Young's modulus display the same tendency. Indeed, the contribution of Al-O-P bonds is significantly higher when the material is thermally resistant ( $58 \%$ instead of less than $45 \%$ for others). Moreover, the absence of unreacted metakaolin in 1-M3-20 suggests that all aluminum must react with phosphorus to obtain a thermal resistant specimen. In such a case Al-O-P bonds acts as fillers in the material, conducting to the thermal resistance. The unreacted metakaolin prevents the creation of these fillers, deteriorating these properties. The higher proportion of Al-O-P bonds and the absence of metakaolin also lead to higher Young's modulus values confirming the presence of stronger 
bonds in the materials (21 GPa for 1-M3-20 against $1 \mathrm{GPa}$ for 4-M3-40). These strongly correlated parameters thus allow to predict the thermal properties of these geopolymers.

The properties of water resistant samples (1-M3-70 and 4-M3-20) as well as the structural data $\left(\mathrm{Q}^{0}(1 \mathrm{Al})\right.$ and $\left.\mathrm{Q}^{1}(2 \mathrm{Al})\right)$ and amount of physisorbed water (Figure $9 \mathrm{~B}$ ) display also the same tendency. The low amount of $\mathrm{Q}^{0}(1 \mathrm{Al})$ and high amount of $\mathrm{Q}^{1}(2 \mathrm{Al})$ in these samples suggest that water resistant materials exhibit a more ordered local environment. The presence of $\mathrm{Q}^{0}(1 \mathrm{Al})$ indeed leads to a disordered structure. The presence of different formed networks also induces a poor cohesion of the material, thus letting water leach into the sample. The study of these parameters give ways to effectively predict the water resistant of sample.

\section{Conclusion}

Acid-based geopolymers can exhibit different working properties such as thermal resistance or water resistance. This study aims to explain these properties from ${ }^{27} \mathrm{Al},{ }^{29} \mathrm{Si}$ and

${ }^{31} \mathrm{P}$ NMR and XRD data. The presence of different networks in the structure of geopolymer materials with different properties was confirmed by the structural analyses. Consolidated geopolymers are mainly constituted of $\mathrm{Al}-\mathrm{O}-\mathrm{P}$ and $\mathrm{Si}(\mathrm{OH})_{4}$ networks. If both $\mathrm{Al} / \mathrm{P}$ ratio and setting temperature increase, some unreacted metakaolin is observed in the samples. After a thermal treatment at $1000^{\circ} \mathrm{C}$, the samples are essentially composed of $\mathrm{AlPO}_{4}$ polymorphs, free amorphous silica and Si-O-P networks. Moreover, for $\mathrm{Al} / \mathrm{P}=4$, mullite phase appears. According to the $\mathrm{Al} / \mathrm{P}$ ratio and the setting temperature, the proportion of networks is different which induces different final properties.

Materials are thermally resistant when they exhibit a high proportion of Al-O-P bonds and no unreacted metakaolin. For water resistance, the geopolymer needs an ordered structure including a low proportion of $\mathrm{Q}^{0}(1 \mathrm{Al})$ and a high amount of $\mathrm{Q}^{1}(2 \mathrm{Al})\left({ }^{31} \mathrm{P}\right.$ NMR data). 
Table 1: Nomenclature of the samples belonging to the four different resistance groups. TR: thermal resistance, WR1 and WR2: water resistance with respectively $\mathrm{Al} / \mathrm{P}=1$ and 4 and $\mathrm{N}$ : none resistance.

\begin{tabular}{lc|cc|cc}
\hline Samples & Group & \multicolumn{2}{|c|}{ Al/P } & \multicolumn{2}{|c}{ Setting temperature $\left({ }^{\circ} \mathrm{C}\right)$} \\
\hline 1-M3-20 & TR & 1 & & 20 & 70 \\
1-M3-70 & WR1 & 1 & & & \\
4-M3-20 & WR2 & & 4 & 20 & \\
4-M3-40 & N & & 4 & & 40 \\
\hline
\end{tabular}

Table 2: Young's modulus of consolidated samples and amount of physisorbed water in the samples after a water resistance test.

\begin{tabular}{l|cccc}
\hline Samples & $\begin{array}{c}\text { 1-M3-20 } \\
\text { Thermal } \\
\text { (TR) }\end{array}$ & $\begin{array}{c}\text { 1-M3-70 } \\
\text { Water } \\
\text { (WR) }\end{array}$ & $\begin{array}{c}\text { 4-M3-20 } \\
\text { Water } \\
\text { (WR) }\end{array}$ & $\begin{array}{c}\text { 4-M3-40 } \\
\text { No } \\
\text { (N) }\end{array}$ \\
\hline Young's modulus value (GPa) & 21 & 16 & 1 & 1 \\
Amount of physisorbed water (\%) & 5.1 & 4.8 & 3.8 & 5.7 \\
\hline
\end{tabular}


Table 3: ${ }^{27} \mathrm{Al},{ }^{29} \mathrm{Si},{ }^{31} \mathrm{P}$ NMR data (chemical shift $\delta$, relative area and full width at half maximum FWHM) for raw metakaolin M3 and 1-M3-20, 1-M3-70, 4-M3-20 and 4-M3-40 samples.

\begin{tabular}{|c|c|c|c|c|c|c|c|c|c|}
\hline Samples & $\begin{array}{c}\delta \\
(\mathrm{ppm})\end{array}$ & $\begin{array}{c}\text { 27Al } \\
\text { Relative } \\
\text { area (\%) }\end{array}$ & FWHM & $\begin{array}{c}\delta \\
(\mathrm{ppm})\end{array}$ & $\begin{array}{c}\text { 29Si } \\
\text { Relative } \\
\text { area (\%) }\end{array}$ & FWHM & $\begin{array}{c}\delta \\
\text { (ppm) }\end{array}$ & $\begin{array}{c}\text { 31P } \\
\text { Relative } \\
\text { area (\%) }\end{array}$ & FWHM \\
\hline M3 [31, 32] & $\begin{array}{c}56 \\
30 \\
1\end{array}$ & $\begin{array}{l}24 \\
31 \\
45\end{array}$ & $\begin{array}{l}29 \\
25 \\
26\end{array}$ & $\begin{array}{l}-96 \\
-107\end{array}$ & $\begin{array}{l}34 \\
59\end{array}$ & $\begin{array}{l}15 \\
15\end{array}$ & & & \\
\hline 1-M3-20 & $\begin{array}{l}-13 \\
-22\end{array}$ & $\begin{array}{l}58 \\
42\end{array}$ & $\begin{array}{l}16 \\
10\end{array}$ & $\begin{array}{c}-90 \\
-94 \\
-102 \\
-106 \\
-111\end{array}$ & $\begin{array}{c}3 \\
9 \\
41 \\
5 \\
42\end{array}$ & $\begin{array}{l}5 \\
6 \\
8 \\
6 \\
8\end{array}$ & $\begin{array}{c}-1 \\
-7 \\
-16\end{array}$ & $\begin{array}{c}4 \\
16 \\
80\end{array}$ & $\begin{array}{c}5 \\
8 \\
12\end{array}$ \\
\hline 1-M3-70 & $\begin{array}{c}43 \\
28 \\
-12 \\
-23\end{array}$ & $\begin{array}{c}8 \\
1 \\
49 \\
42\end{array}$ & $\begin{array}{l}15 \\
10 \\
12 \\
20\end{array}$ & $\begin{array}{c}-90 \\
-94 \\
-102 \\
-106 \\
-112\end{array}$ & $\begin{array}{c}4 \\
5 \\
35 \\
4 \\
52\end{array}$ & $\begin{array}{l}5 \\
5 \\
6 \\
7 \\
8\end{array}$ & $\begin{array}{c}1 \\
-7 \\
-16\end{array}$ & $\begin{array}{c}1 \\
9 \\
90\end{array}$ & $\begin{array}{c}6 \\
8 \\
14\end{array}$ \\
\hline 4-M3-20 & $\begin{array}{c}50 \\
28 \\
9 \\
-10 \\
-23\end{array}$ & $\begin{array}{c}8 \\
15 \\
4 \\
44 \\
29\end{array}$ & $\begin{array}{l}20 \\
25 \\
15 \\
13 \\
18\end{array}$ & $\begin{array}{l}-90 \\
-95 \\
-101 \\
-106 \\
-111\end{array}$ & $\begin{array}{c}9 \\
17 \\
36 \\
19 \\
19\end{array}$ & $\begin{array}{l}7 \\
7 \\
8 \\
7 \\
7\end{array}$ & $\begin{array}{c}0 \\
-6 \\
-11 \\
-16\end{array}$ & $\begin{array}{c}2 \\
13 \\
9 \\
76\end{array}$ & $\begin{array}{c}5 \\
7 \\
7 \\
13\end{array}$ \\
\hline 4-M3-40 & $\begin{array}{c}49 \\
27 \\
-10 \\
-22\end{array}$ & $\begin{array}{l}10 \\
17 \\
43 \\
30\end{array}$ & $\begin{array}{l}20 \\
26 \\
13 \\
20\end{array}$ & $\begin{array}{c}-90 \\
-95 \\
-101 \\
-105 \\
-110\end{array}$ & $\begin{array}{c}7 \\
14 \\
37 \\
12 \\
30\end{array}$ & $\begin{array}{l}5 \\
6 \\
7 \\
6 \\
7\end{array}$ & $\begin{array}{l}-2 \\
-9 \\
-16\end{array}$ & $\begin{array}{c}3 \\
19 \\
78\end{array}$ & $\begin{array}{c}5 \\
8 \\
13\end{array}$ \\
\hline
\end{tabular}


Table 4: ${ }^{27} \mathrm{Al},{ }^{29} \mathrm{Si},{ }^{31} \mathrm{P}$ NMR data (chemical shift $\delta$, relative area and full width at half maximum FWHM) for 1-M3-20, 1-M3-70, 4-M3-20 and 4M3-40 samples after a calcination at $1000^{\circ} \mathrm{C}$.

\begin{tabular}{|c|c|c|c|c|c|c|c|c|c|}
\hline Samples & $\begin{array}{c}\delta \\
(\mathrm{ppm})\end{array}$ & $\begin{array}{c}\text { 27Al } \\
\text { Relative } \\
\text { area (\%) }\end{array}$ & FWHM & $\begin{array}{c}\delta \\
(\mathrm{ppm})\end{array}$ & $\begin{array}{c}\text { 29Si } \\
\text { Relative } \\
\text { area (\%) }\end{array}$ & FWHM & $\begin{array}{c}\delta \\
(p p m)\end{array}$ & $\begin{array}{c}\text { 31P } \\
\text { Relative } \\
\text { area (\%) }\end{array}$ & FWHM \\
\hline 1-M3-20 & 39 & 100 & 4 & $\begin{array}{l}-104 \\
-114 \\
-124\end{array}$ & $\begin{array}{c}2 \\
97 \\
1\end{array}$ & $\begin{array}{c}3 \\
10 \\
3\end{array}$ & $\begin{array}{l}-28 \\
-31 \\
-38\end{array}$ & $\begin{array}{c}37 \\
54 \\
9\end{array}$ & $\begin{array}{c}3 \\
4 \\
10\end{array}$ \\
\hline 1-M3-70 & 40 & 100 & 5 & $\begin{array}{l}-106 \\
-113 \\
-122\end{array}$ & $\begin{array}{c}5 \\
94 \\
1\end{array}$ & $\begin{array}{c}6 \\
12 \\
3\end{array}$ & $\begin{array}{l}-28 \\
-30 \\
-38\end{array}$ & $\begin{array}{c}43 \\
56 \\
1\end{array}$ & $\begin{array}{c}3 \\
4 \\
10\end{array}$ \\
\hline 4-M3-20 & $\begin{array}{c}57 \\
40 \\
1\end{array}$ & $\begin{array}{c}7 \\
75 \\
18\end{array}$ & $\begin{array}{c}25 \\
5 \\
25\end{array}$ & $\begin{array}{l}-86 \\
-89 \\
-94 \\
-105 \\
-112 \\
-125\end{array}$ & $\begin{array}{c}1 \\
1 \\
1 \\
4 \\
92 \\
1\end{array}$ & $\begin{array}{c}6 \\
6 \\
6 \\
6 \\
12 \\
3\end{array}$ & $\begin{array}{l}-28 \\
-31 \\
-38\end{array}$ & $\begin{array}{c}65 \\
34 \\
1\end{array}$ & $\begin{array}{c}4 \\
4 \\
10\end{array}$ \\
\hline 4-M3-40 & $\begin{array}{c}57 \\
40 \\
1\end{array}$ & $\begin{array}{c}7 \\
76 \\
17\end{array}$ & $\begin{array}{c}25 \\
5 \\
25\end{array}$ & $\begin{array}{l}-89 \\
-96 \\
-99 \\
-110 \\
-115\end{array}$ & $\begin{array}{c}5 \\
4 \\
2 \\
72 \\
17\end{array}$ & $\begin{array}{c}6 \\
6 \\
4 \\
11 \\
8\end{array}$ & $\begin{array}{l}-28 \\
-31\end{array}$ & $\begin{array}{l}54 \\
46\end{array}$ & $\begin{array}{l}4 \\
4\end{array}$ \\
\hline
\end{tabular}




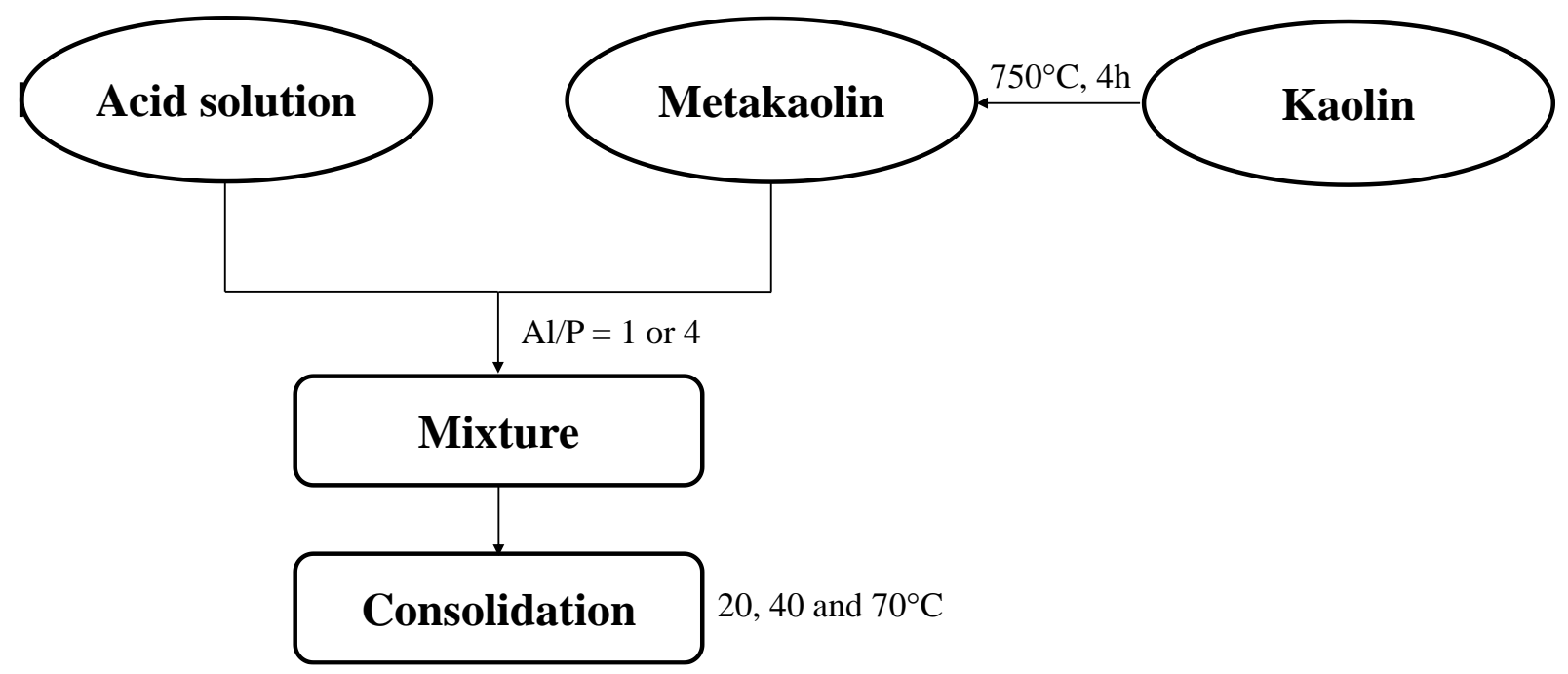

Figure 1: Synthesis chart of acid-based geopolymers.

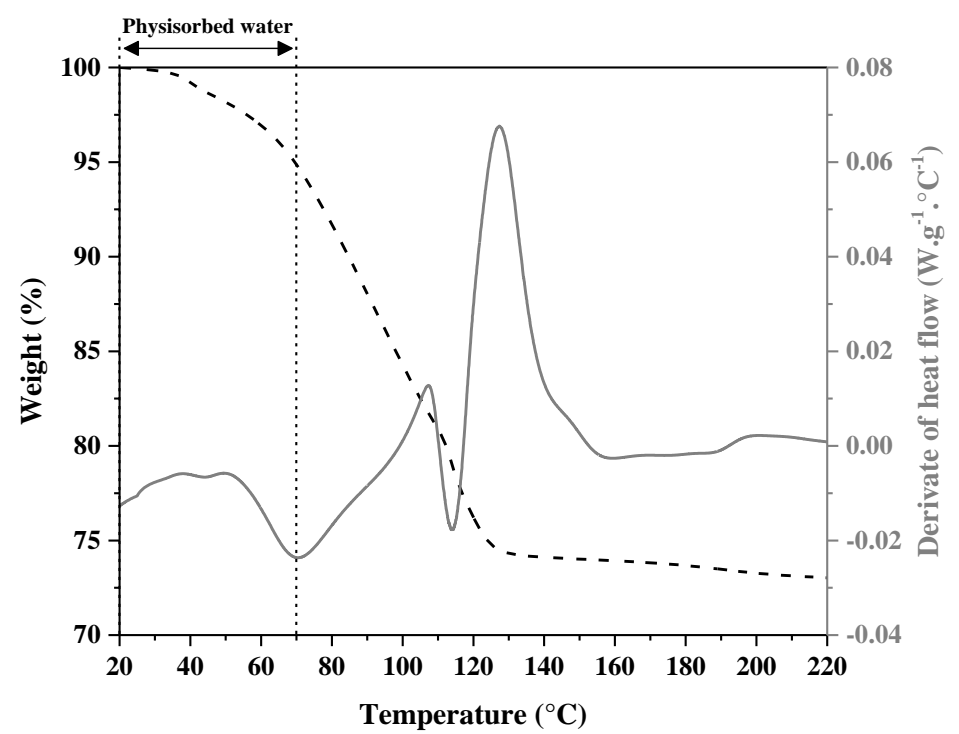

Figure 2 : Weight loss (dash) and derivate of heat flow (line) curves of 1-M3-20 (TR) sample. 
(A)

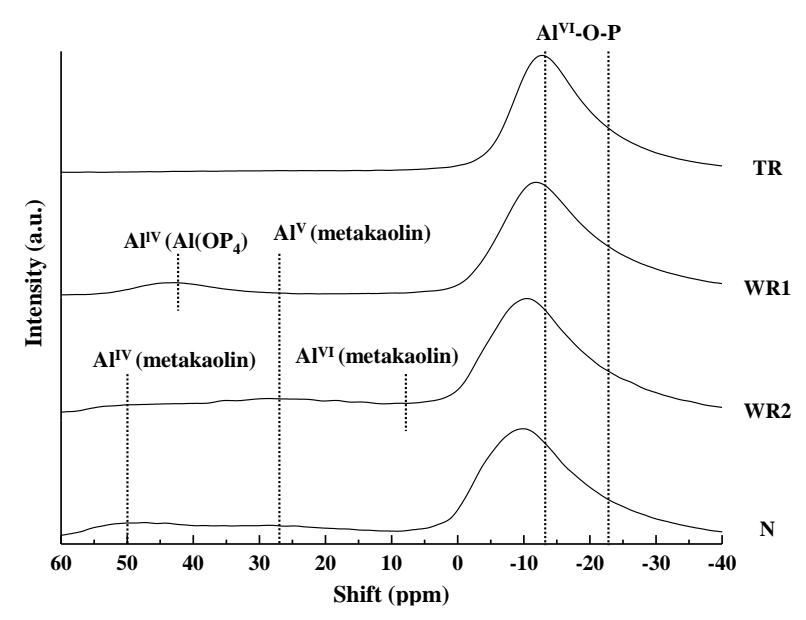

(B)

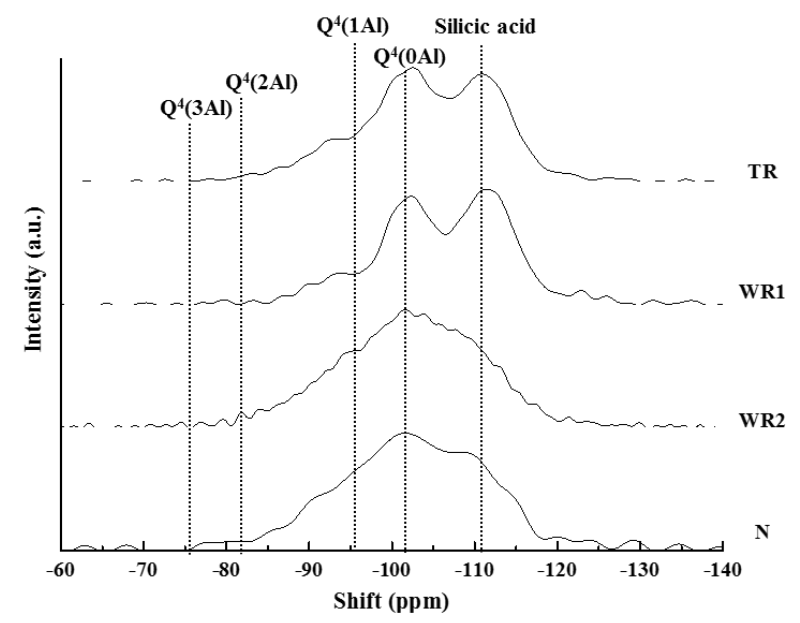

(C)

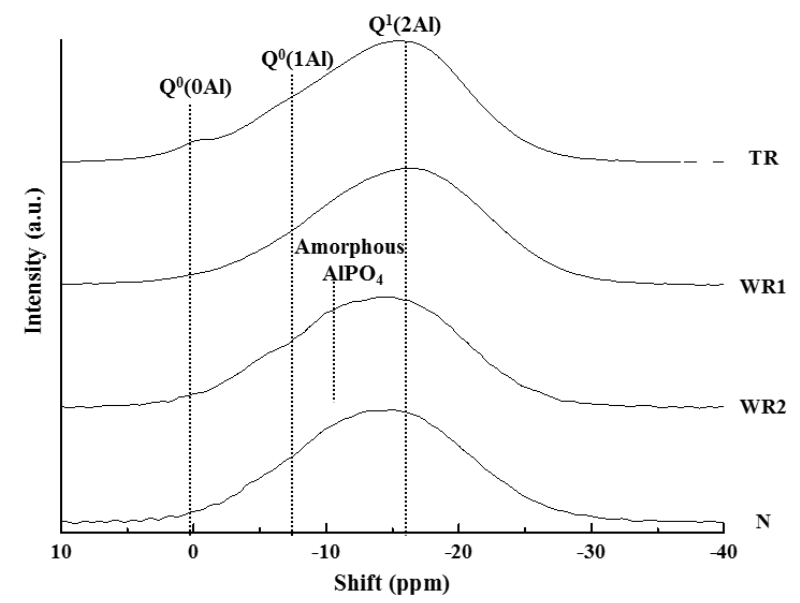

Figure 3: NMR spectra of (A) ${ }^{27} \mathrm{Al}$, (B) ${ }^{29} \mathrm{Si}$ and (C) ${ }^{31} \mathrm{P}$ for (TR) 1-M3-20, (WR1) 1-M3-70, (WR2) 4-M3-20 and (N) 4-M3-40 samples after their consolidation. 
(A)

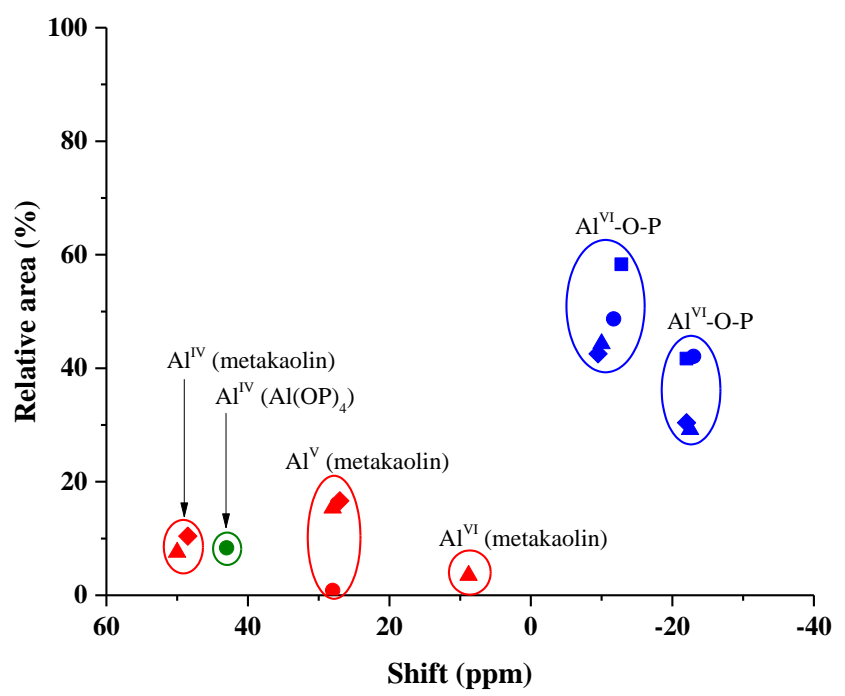

(B)

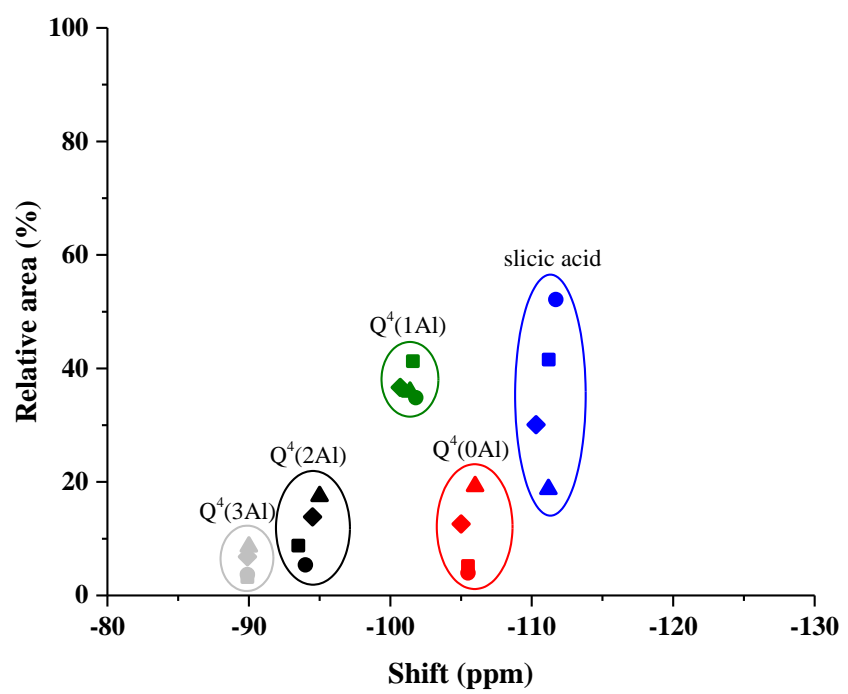

(C)

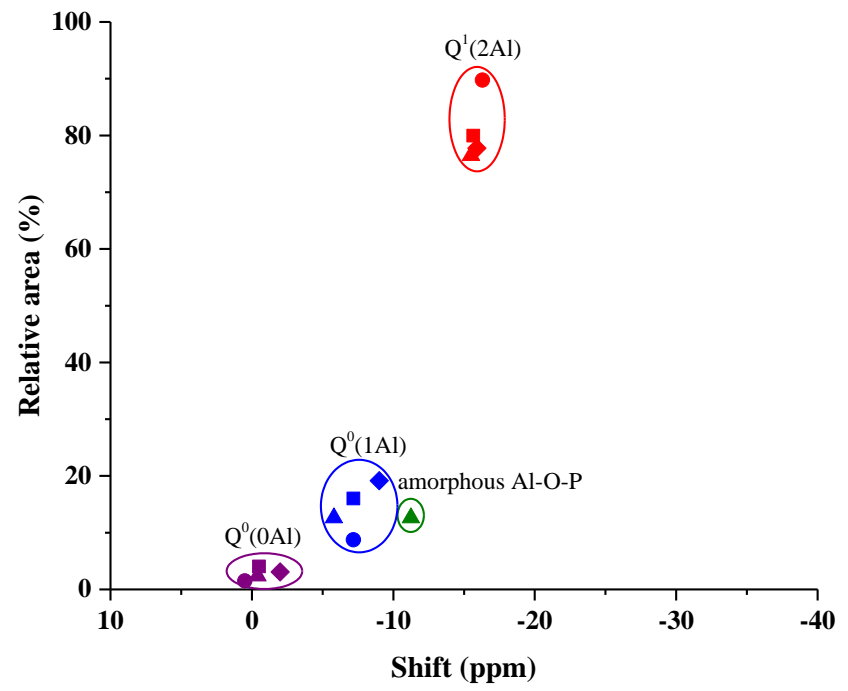

Figure 4: Relative area of NMR contributions as a function of the shift measured in $(\mathrm{A}){ }^{27} \mathrm{Al},(\mathrm{B})$

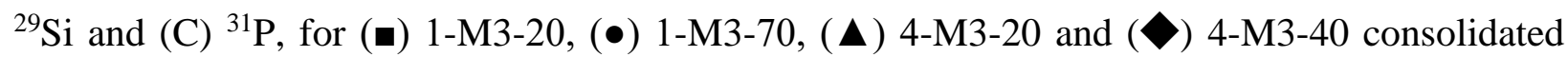
samples. 
(A)

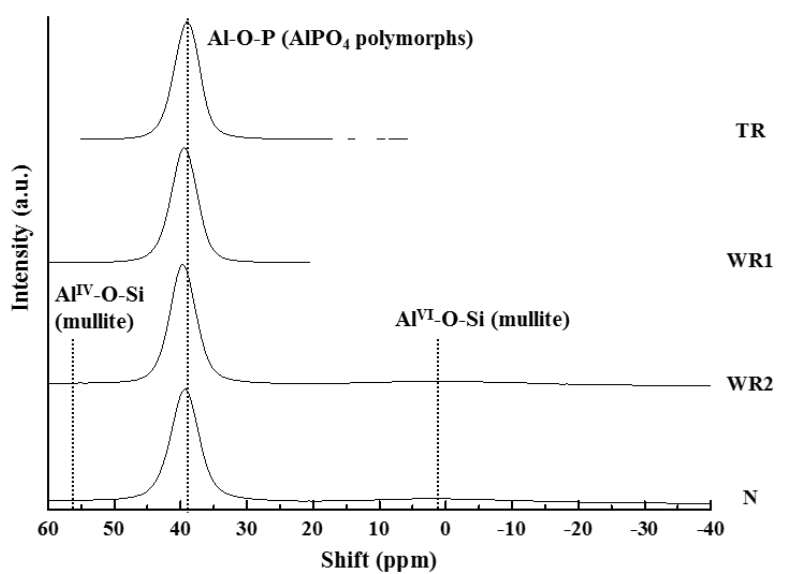

(B)

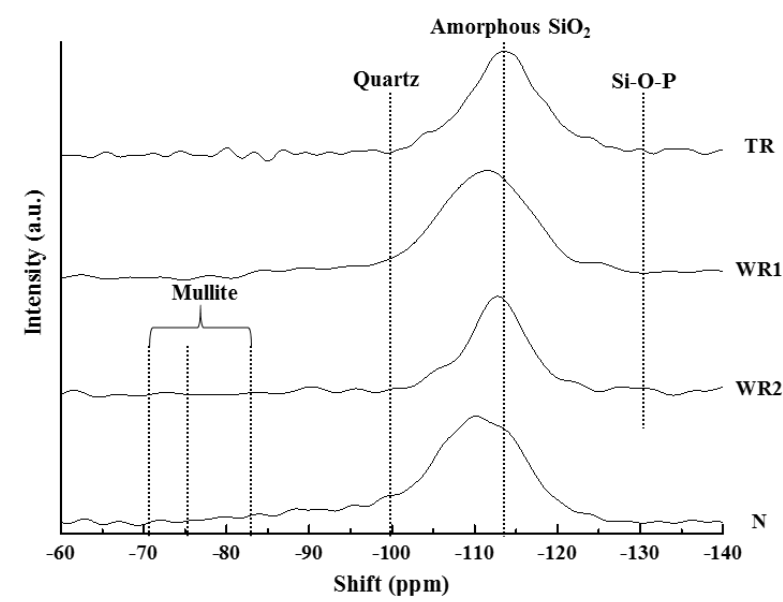

(C)

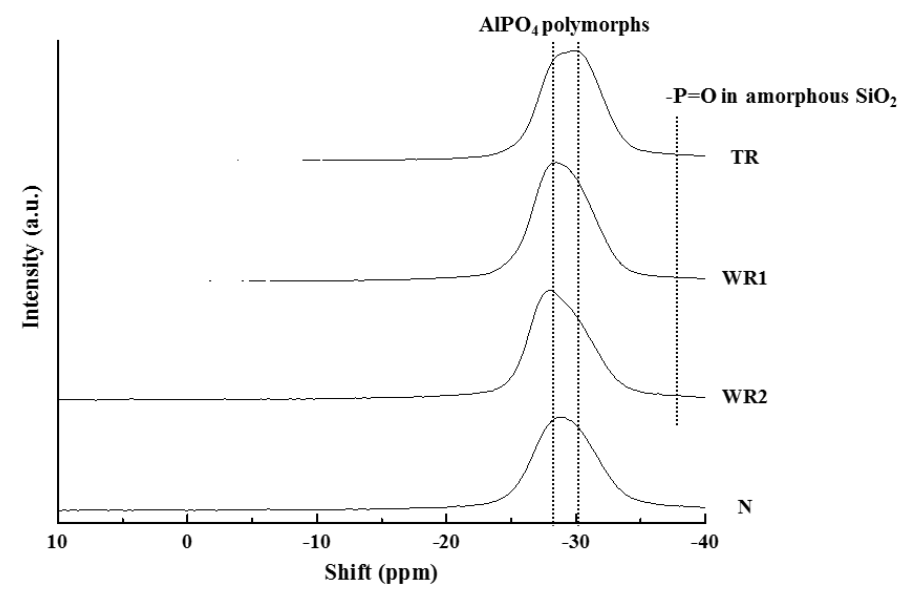

Figure 5: NMR spectra of (A) 27Al, (B) 29Si and (C) 31P for (TR) 1-M3-20, (WR1) 1-M3-70, (WR2) 4-M3-20 and (N) 4-M3-40 samples after a calcination at $1000^{\circ} \mathrm{C}$. 
(A)

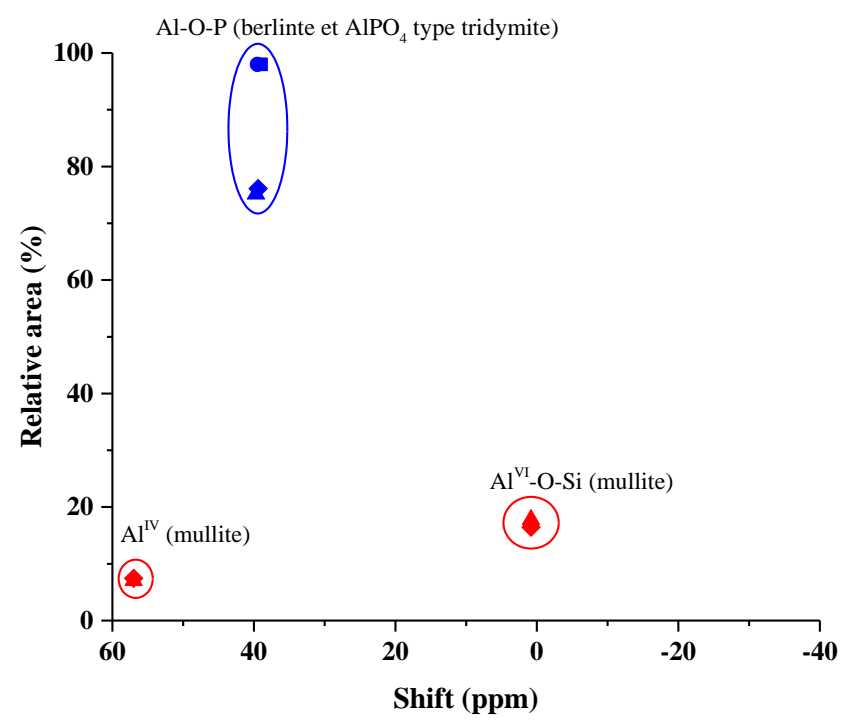

(B)

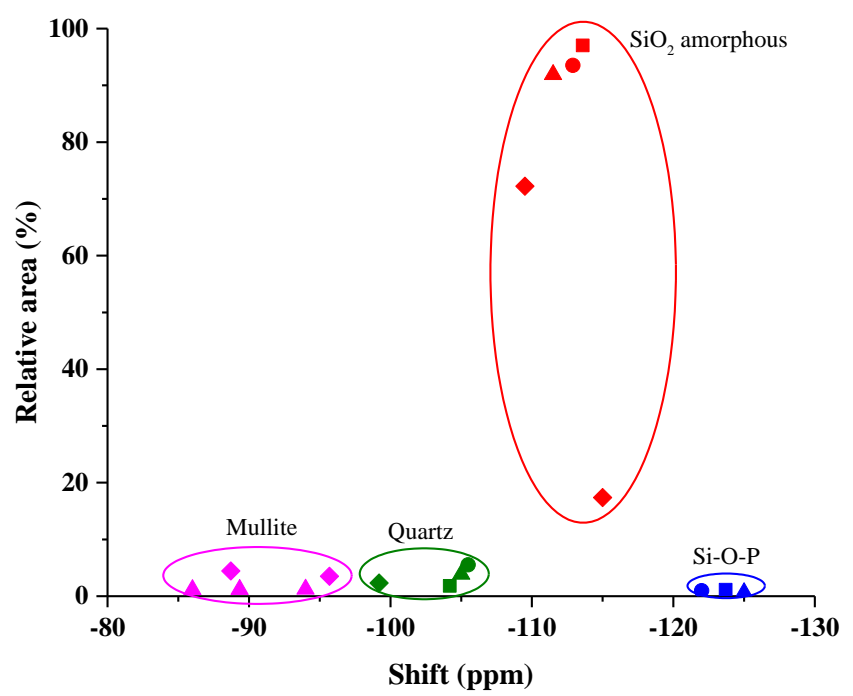

(C)

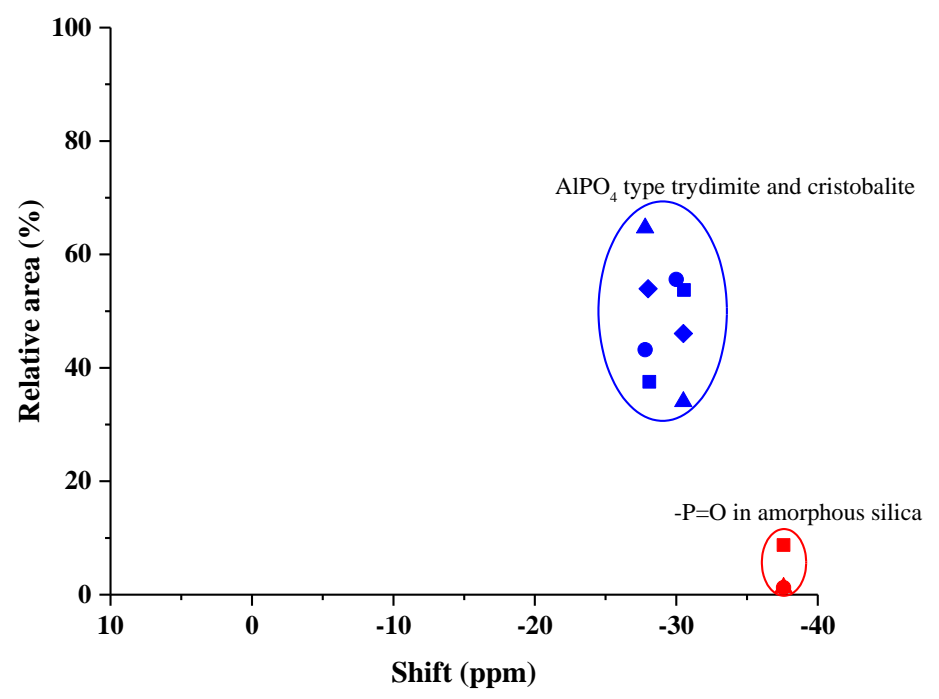

Figure 6: Relative area of NMR spectra as a function of the shift measured in $(\mathrm{A}){ }^{27} \mathrm{Al}$, (B) ${ }^{29} \mathrm{Si}$

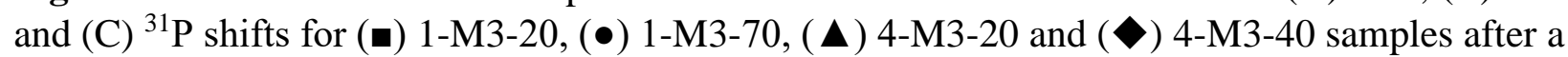
calcination at $1000^{\circ} \mathrm{C}$. 
(A)

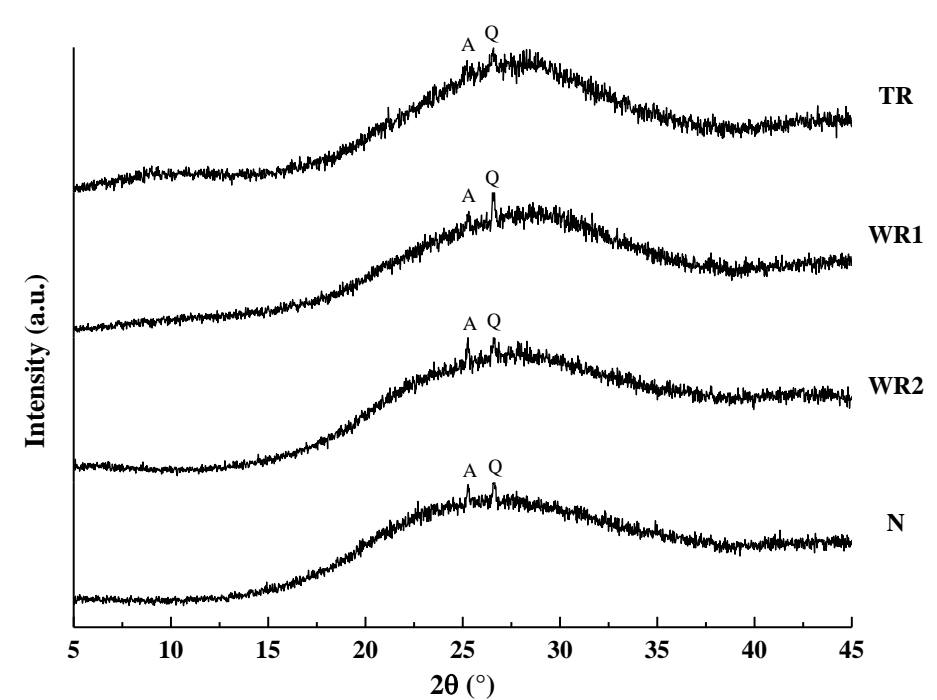

(B)

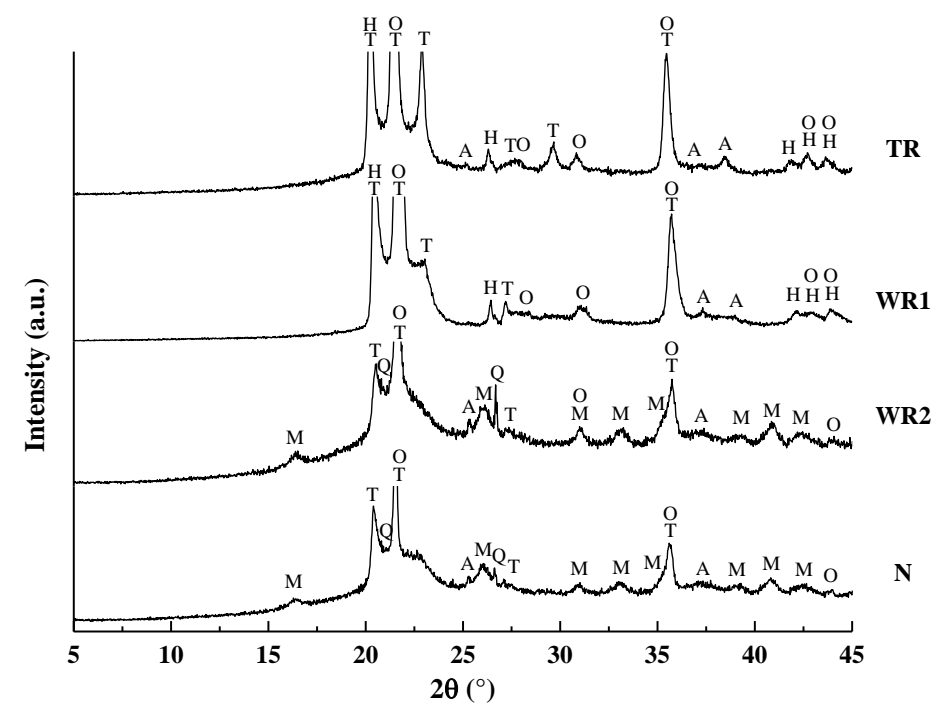

Figure 7: XRay diagrams (A) before and (B) after a calcination at $1000^{\circ} \mathrm{C}$ of (TR) 1-M1-20, (WR1) 4-M3-70, (WR2) 1-M4-70, and (N) 4-M4-20 samples. The following crystalline phases were identified: A: anatase (PDF n $\left.{ }^{\circ} 00-021-1272\right)$, Q: quartz (PDF n 00-046-1045), T: AlPO4 triclinic (PDF n ${ }^{\circ}$ 04-012-4467), O: AlPO4 orthorombic (PDF $n^{\circ}$ 04-009-3674), H: berlinite (PDF $\mathrm{n}^{\circ}$ 01-089-4201), Ah: Al(H2PO4)3 (PDF n ${ }^{\circ}$ 00-014-0377) and M: mullite (PDF $\mathrm{n}^{\circ}$ 01-074-2419). 


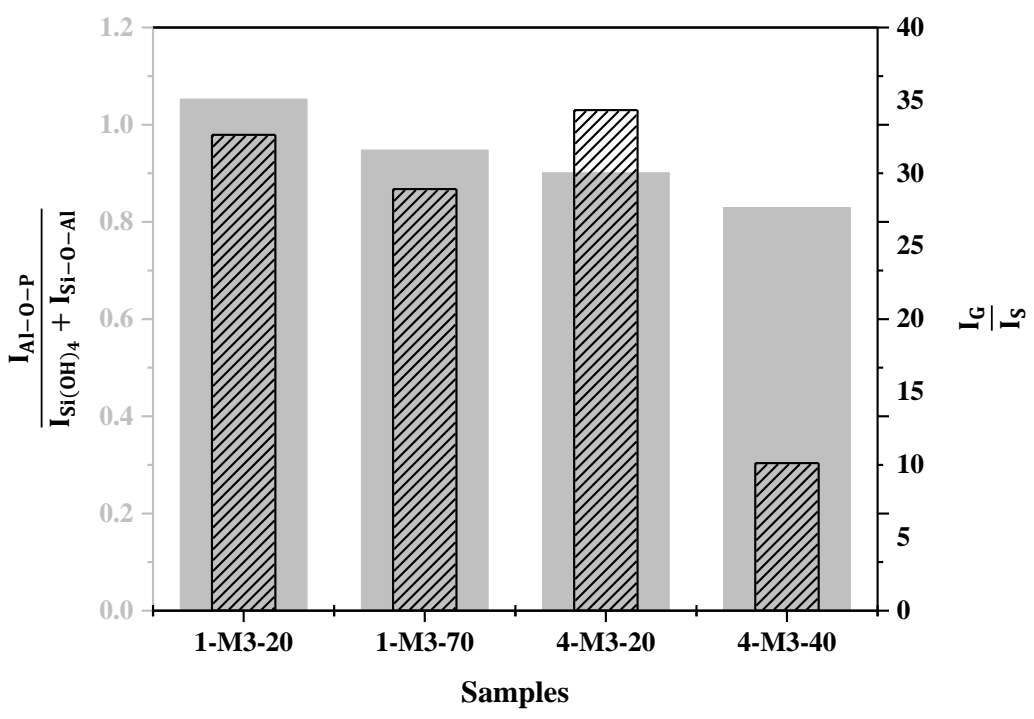

Figure 8: Values of $\frac{I_{A l-O-P}}{I_{S i(O H)_{4}+I_{S i-O-A l}}}(\square)$ and $\frac{I_{G}}{I_{S}}$ (浛) ratios according to XRD and NMR data respectively (with the different following contribution: $\mathrm{I}_{\mathrm{G}}$ geopolymeric networks at $27^{\circ}$, IS amorphous silica at $22^{\circ}$, I $\mathrm{Al}-\mathrm{O}-\mathrm{P} \mathrm{Al}-\mathrm{O}-\mathrm{P}$ bonds at -13 and $-22 \mathrm{ppm}$ on ${ }^{27} \mathrm{Al} \mathrm{NMR,} \mathrm{I}_{\mathrm{Si}(\mathrm{OH}) 4}$ silicic acid at $-111 \mathrm{ppm}$ on ${ }^{29} \mathrm{Si}$ NMR and ISi-O-Al Si-O-Al bonds at $-90,-94$, and $-102 \mathrm{ppm}$ on 29Si NMR) for the four studied samples. 
(A)

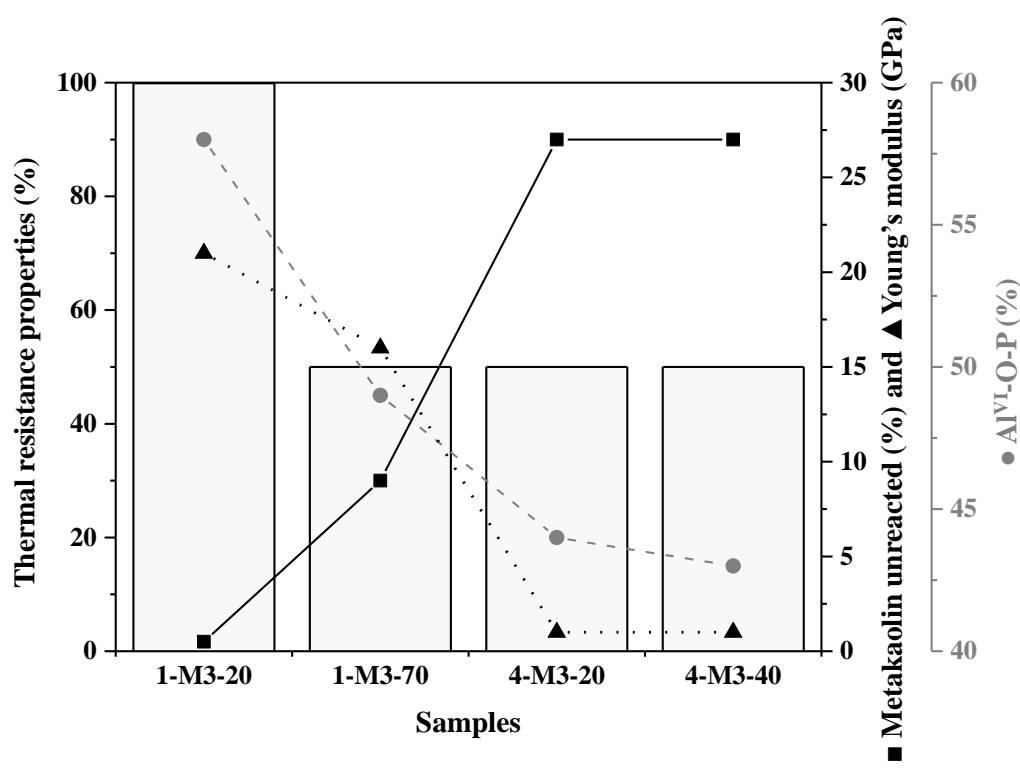

(B)

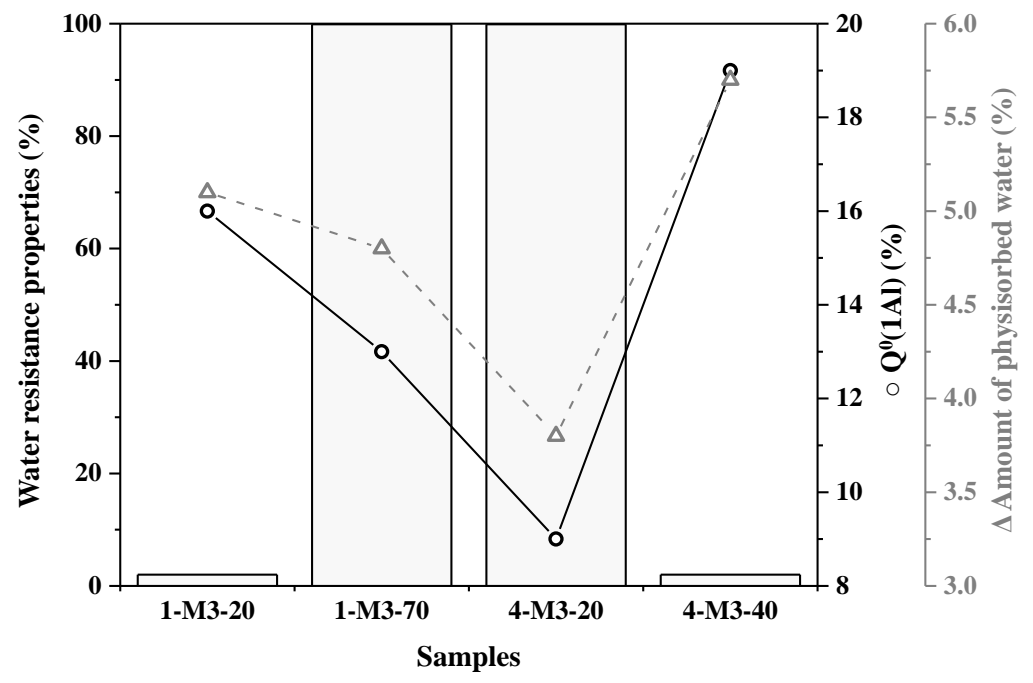

Figure 9: (A) Thermal resistance (histogram), values of contributions of ( $\mathbf{\square})$ unreacted metakaolin at 50, 28 and $9 \mathrm{ppm},(\bullet) \mathrm{Al}^{\mathrm{VI}}-\mathrm{O}-\mathrm{P}$ located at $-13 \mathrm{ppm}$ on ${ }^{27} \mathrm{Al}$ NMR and $(\boldsymbol{\Delta})$ Young's modulus of untreated samples. (B) Water resistance (histogram), values of $(\circ) \mathrm{Q}^{0}(1 \mathrm{Al})$ at $-7 \mathrm{ppm}$ on ${ }^{31} \mathrm{P} \mathrm{NMR}$ and $(\Delta)$ amount of physisorbed water in saturated samples as a function of each sample.

\section{References}

[i] J. Davidovits, Geopolymer: chemistry and applications, second ed. Geopolymer institute, Saint-Quentin, France, 2008. 
[ii] A. Gharzouni, Contrôle de l'attaque des sources aluminosilicates par la comprehension des solutions alcalines, Thèse de doctorat, Université de Limoges et de Sfax, 2016.

[iii] L. Le-ping, C. Xue-min, Q. Shu-heng, Y. Jun-li, Z. Lin, Preparation of phosphoric acid-based porous geopolymers, Appl. Clay Sci., 50 (2010), 600-603. https://doi.org/10.1016/j.clay.2010.10.004.

[iv] H.K. Tchakouté and C.H. Rüscher, Mechanical and microstructural properties of metakaolin-based geopolymer cements from sodium waterglass and phosphoric acid solution as hardeners: A comparative study, Appl. Clay Sci., 140 (2017), 81-87. http://dx.doi.org/10.1016/j.clay.2017.02.002.

[v] S. Louati, S. Baklouti, B. Samet, Acid based geopolymerization kinetics: Effect of clay particle size, Appl. Clay Sci., 132-133 (2016), 571-578. http://dx.doi.org/10.1016/j.clay.2016.08.007.

[vi] D.S. Perera, J.V. Hanna, J. Davis, M.G. Blackford, B.A. Latella, Y. Sasaki, E.R. Vance, Relative strengths of phosphoric acid-reacted and alkali-reacted metakaolin materials, J Mater Sci, 43 (2008), 6562-6566. https://doi.org/10.1007/s10853-008-2913-6.

[vii] H. Douiri, S. Louati, S. Baklouti, M. Arous, Z. Fakhfakh, Structural, thermal and dielectric properties of phosphoric acid-based geopolymers with different amounts of $\mathrm{H}_{3} \mathrm{PO}_{4}$, Mater. Lett., 116 (2014), 9-12. http://dx.doi.org/10.1016/j.matlet.2013.10.075.

[viii] H. Celerier, J. Jouin, N. Tessier-Doyen, S. Rossignol, Influence of various metakaolin raw materials on the water and fire resistance of geopolymers prepared in phosphoric acid, J. Non-Cryst. Solids, $500 \quad$ (2018), 493-501. https://doi.org/10.1016/j.jnoncrysol.2018.09.005.

[ix] Christelle Nobouassia Bewa, Hervé K. Tchakouté, Daniel Fotio, Claus H. Rüscher, Elie Kamseu \& Cristina Leonelli (2018) Water resistance and thermal behavior of metakaolinphosphate-based geopolymer cements, Journal of Asian Ceramic Societies, 6:3,271-283, DOI: 10.1080/21870764.2018.1507660.

[x] Cheng-Yong, H. et al. Thermal Resistance Variations of Fly Ash Geopolymers: Foaming Responses. Sci. Rep. 7, 45355; doi: 10.1038/srep45355 (2017).

[xi] H. Suzuki, H. Saito, Low temperature synthesis of glassy solids of the system $\mathrm{Al}_{2} \mathrm{O}_{3}-\mathrm{P}_{2} \mathrm{O}_{5}-\mathrm{SiO}_{2}$, J. Mater. Sci., 19 (1984), 396-402. https://doi.org/10.1007/BF02403225.

[xii] Y. Gandhi, M.V. Ramachandra Rao, Ch. Srinvasa Rao, T. Srikumar, I.V. Kityk et al, Influence of aluminium ions on fluorescent spectra and upconversion in codoped $\mathrm{CaF}_{22-}$ 
$\mathrm{Al}_{2} \mathrm{O}_{3}-\mathrm{P}_{2} \mathrm{O}_{5}-\mathrm{SiO}_{2}: \mathrm{Ho}^{3+}$ and $\mathrm{Er}^{3+}$ glass system, J. Appl. Phys., 108 (2010), 023102. http://dx.doi.org/10.1063/1.3464257.

[xiii] R.K. Brow, R.J. Kirkpatrick, G.L. Turner, Nature of alumina in phosphate glass: II, structure of sodium aluminophosphate glass, J Am. Ceram. Soc., 76 [4] (1993), 919-928. https://doi.org/10.1111/j.1151-2916.1993.tb05316.x.

[xiv] G. Tricot, B. Doumert, B. Revel, M. Bria, J. Trebosc, H. Vezin, Nonhomogeneous distribution of $\mathrm{Al}^{3+}$ in doped phosphate glasses revealed by ${ }^{27} \mathrm{Al} /{ }^{31} \mathrm{P}$ solid state NMR, Solid State Nucl. Magn. Reson., 84 (2017), 137-142. http://dx.doi.org/10.1016/j.ssnmr.2017.02.003.

[xv] J. Varlec, A. Krajnc, M. Mazaj, A. Ristić, K. Vanatalu, A Oss, A. Samoson, V. Kaučič, G. Mali, Dehydration of $\mathrm{AlPO}_{4}-34$ studied by variable-temperature NMR, XRD and first-principles calculations, New J. Chem., 40 (2016), 4178-4186. DOI: 10.1039/c5nj02838h.

[xvi] S. Xu, Z. Zhao, M.Y. Hu, X. Han, J.Z. Hu, X.Bao, Investigation of water assisted phase transformation process from $\mathrm{AlPO}_{4}-5$ to $\mathrm{AlPO}_{4}$-trydimite, Microporous and Mesoporous Materials, 223 (2016), 241-246. https://doi.org/10.1016/j.micromeso.2015.10.039.

[xvii] H. Graetsch, Two forms of aluminium phosphate tridymite from X-ray powder data, Acta Crystallogr., Sect. C, 56 (2000), 401-403. https://doi.org/ 10.1107/S0108270199015164.

[xviii] R.C.L. Mooney, The crystal structure of aluminium phosphate and gallium phosphate, low-cristobalite type, Acta Crystallogr., 9 (1956), 728-734. https://doi.org/10.1107/S0365110X56001996.

[xix] R. Dupree, D. Holland, M.G. Mortuza, Six-coordinated silicon in glasses, Nature, 328 (1987), 416-417. https://doi.org/10.1038/328416a0.

[xx] J.E. Dickinson Jr, B.H.W.S. de Jong, Hydorgen-containing glass and gasceramic microfoams: RAMAN, XPS, and MAS-NMR results on the structure of precursor $\mathrm{SiO}_{2}-\mathrm{B}_{2} \mathrm{O}_{3}-\mathrm{P}_{2} \mathrm{O}_{5} \quad$ glasses, J. Non-Cryst. Solids, $102 \quad$ (1988), 196-204. https://doi.org/10.1016/0022-3093(88)90132-9.

[xxi] D. Li, M.E. Fleet, G.M. Bancroft, M. Kasrai, Y. Pan, Local structure of Si and P in $\mathrm{SiO}_{2}-\mathrm{P}_{2} \mathrm{O}_{5}$ and $\mathrm{Na}_{2} \mathrm{O}-\mathrm{SiO}_{2}-\mathrm{P}_{2} \mathrm{O}_{5}$ glasses: a XANES study, J. Non-Cryst. Solids, 188 (1995), 181-189. https://doi.org/10.1016/0022-3093(95)00100-X.

[xxii] T.L. Weeding, B.H.W.S de Jong, W.S. Veeman, B.G. Aitken, Silicon coordination changes from 4-fold to 6-fold on devitrification of silicon phosphate glass, Nature, 318 (1985), 352-353. https://doi.org/10.1038/318352a0. 
[xxiii] B. Zagrajczuk, M. Dziadek, Z. Olejniczak, B. Sulikowski, K. CholewaKowalska, M. Laczka, Structural investigation of gel-derived materials from the $\mathrm{SiO}_{2}-\mathrm{Al}_{2} \mathrm{O}_{3}$ System, J. Mol. Struct., 1167 (2018), 23-32. https://doi.org/10.1016/j.molstruc.2018.04.085.

[xxiv] L.H. Merwin, A. Sebald, H. Rager, H. Schneider, ${ }^{29} \mathrm{Si}$ and ${ }^{27}$ A1 MAS NMR Spectroscopy of Mullite, Phys Chem Miner., 18 (1991), 47-52. https://doi.org/10.1007/BF00199043.

[xxv] M.A. Aramendía, V. Boráu, C. Jiménez, J.M. Marinas, J.R. Ruiz, F.J. Urbano, MAS NMR, DRIFT, and FT-Raman characterization of $\mathrm{SiO}_{2}-\mathrm{AlPO}_{4}-\mathrm{B}_{2} \mathrm{O}_{3}$ Ternary Catalytic Systems, J. Colloid Interface Sci., 217 (1999), 186-193. https://doi.org/10.1006/jcis.1999.6360.

[xxvi] G.D. Cody, B. Mysen, G. Sághi-Szabó, J.A. Tossell, Silicate-phosphate interactions in silicate glasses and melts: I. A multinuclear $\left({ }^{27} \mathrm{Al},{ }^{29} \mathrm{Si},{ }^{31} \mathrm{P}\right)$ MAS NMR and ab initio chemical shielding $\left({ }^{31} \mathrm{P}\right)$ study of phosphorous speciation in silicate glasses, Geochim. Cosmochim. Acta, 65[14] (2001), 2395-2411. https://doi.org/10.1016/S0016-7037(01)00597$\mathrm{X}$.

[xxvii] D.J. DiGiovanni, J.B. MacChesney, T.Y. Kometani, Structure and properties of silica containing aluminum and phosphorus near the AlPO4 join, J. Non-Cryst. Solids, 113 (1989), 58-64. https://doi.org/10.1016/0022-3093(89)90318-9.

[xxviii] S.G. Kosinski, D.M. Krol, T.M. Duncan, D.C. Douglass, J.B. MacChesney, J.R. Simpson, Raman and NMR spectroscopy of SiO2 glasses co-doped with A12O3 and P2O5, J. Non-Cryst. Solids, 105 (1988), 45-52. https://doi.org/10.1016/00223093(88)90336-5.

[xxix] L. Le-ping, C. Xue-min, H. Yan, L. Si-dong, G. Si-yu, The phase evolution of phosphoric acid-based geopolymers at elevated temperatures, Mater. Lett., 66 (2012), 10-12. https://doi.org/10.1016/j.matlet.2011.08.043.

[xxx] M.L. Gualtieri, M. Romagnoli, A.F. Gualtieri, Preparation of phosphoric acidbased geopolymer foams using limestone as pore forming agent - Thermal properties by in situ XRPD and Rietveld refinements, J. Eur. Ceram. Soc., 35 (2015), 3167-3178. https://doi.org/10.1016/j.jeurceramsoc.2015.04.030.

[xxxi] C. Guo, K. Wang, M. Liu, X. Li, X. Cui, Preparation and characterization of acid-based geopolymer using metakaolin and disused polishing liquid, Ceram. Int., 42 (2016), 9287-9291. https://doi.org/10.1016/j.ceramint.2016.02.073.

[xxxii] A. Gharzouni, I Sobrados, E. Joussein, S. Baklouti, S. Rossignol, Control of polycondensation reaction generated from different metakaolins and alkaline solutions, J. Ceram. Sci. Technol., 08 [3] (2017), 365-376. https://doi.org/10.4416/JCST2017-00040. 
[xxxiii] N. Tessier-Doyen, J.-C. Glandus, M. Huger, Experimental and 2D-numérical study of elastic behavior of heterogeneous materials with spherical inclusions, J. Mater. Sci., 42 (2007), 5826-5834. https://doi.org/10.1007/s10853-006-1386-8.

[xxxiv]O. Masson, PEAKOC profile fitting software v1.0, 2006, access at http://www.esrf.eu/Instrumentation/software/data-analysis/OurSoftware/PEAKOC.

[xxxv] A. Autef, Formulation géopolymère : influence des rapports molaires $\mathrm{Si} / \mathrm{K}$ et $\mathrm{Si} / \mathrm{Al}$ sur les reactions de polycondensation au sein des gels aluminosilicatés, Thèse de doctorat, Université de Limoges, 2013.

[xxxvi]Y. He, L. Liu, L. He, X. Cui, Characterization of chemosynthetic $\mathrm{H}_{3} \mathrm{PO}_{4}-\mathrm{Al}_{2} \mathrm{O}_{3}-$ $2 \mathrm{SiO}_{2}$ geopolymers, Ceram. Int., 42 (2016), 10908-10912. https://doi.org/10.1016/j.ceramint.2016.03.224.

[xxxvii] Y. Fang, X. Li, X. Liang, S. Wang, X. Gao, Z. Zhang, Characterization and fluorine-free microwave hydrothermal synthesis of $\mathrm{AlPO}_{4}-5$ molecular sieves as adsorbents, J. Porous Mater., 24 (2017), 315-325. https://doi.org/10.1007/s10934-016-0265-1.

[xxxviii] B. Chen, Y. Huang, Formation of microporous material $\mathrm{AlPO}_{4}-18$ under dry-gel conversion conditions, Microporous Mesoporous Mater., 143 (2011), 14-21. https://doi.org/10.1016/j.micromeso.2011.02.002.

[xxxix]A. Autef, E. Joussein, A. Poulesquen, G. Gasgnier, S. Proniere, I. Sobrados, J. Sanz, S. Rossignol, Influence of metakaolin purities on potassium geopolymer formulation : The existence of several networks, J. Colloid Interface Sci., 408 (2013), 43-53. https://doi.org/10.1016/j.jcis.2013.07.024.

[xl] L.V. Wullen, G. Tricot, S. Wegner, An advanced NMR protocol for the structural characterization of aluminophosphate glasses, Solid State Nucl. Magn. Reson., 32 (2007), 44-52. https://doi.org/10.1016/j.ssnmr.2007.07.004.

[xli] S. Wegner, L.V. Wullen et G. Tricot, The structure of aluminophosphate glasses revisited: Application of modern solid state NMR strategies to determine structural motifs on intermediate length scales, J. Non-Cryst. Solids, 354 (2008), 1703-1714. https://doi.org/10.1016/j.jnoncrysol.2007.10.034.

[xlii] J. Davidovits, Structural characterization of geopolymeric materials with X-ray diffractometry and MAS-NMR spectrometry. Geopolymer '88 - First European Conference on Soft Mineralurgy, Compiègne, France, Université de Technologie de Compiègne, 1988.

[xliii] Y. Xiao and R.J. Kirkpatrick, Nuclear magnetic resonance investigations of the structural phase transitions of $\mathrm{AlPO}_{4}$ tridymite, J. Mater. Res., 10[10] (1995), 2586-2591. https://doi.org/10.1557/JMR.1995.2586. 
[xliv] R.H. Meinhold, K.J.D. MacKenzie, I.W.M. Brown, Thermal reactions of kaolinite studied by solid state ${ }^{27} \mathrm{Al}$ and ${ }^{29} \mathrm{Si} \mathrm{NMR}$, Journal of Materials Science Letters, 4 (1985), 163-166. https://doi.org/10.1007/BF00728065.

[xlv] I. Jaymes, A. Douy, P. Florian, D. Massiot, J.P. Coutures, New Synthesis of Mullite. Structural Evolution Study by ${ }^{17} \mathrm{O},{ }^{27} \mathrm{Al}$ and ${ }^{29}$ Si MAS NMR Spectroscopy, J. Sol-Gel Sci. Technol., 2 (1994), 367-370. https://doi.org/10.1007/BF00486272.

[xlvi] S.P. Szu, L.C. Klein, M. Greenblatt, Effect of precursors on the structure of phosphosilicate gels: ${ }^{29} \mathrm{Si}$ and ${ }^{31} \mathrm{P}$ MAS-NMR study, J. Non-Cryst. Solids, 143 (1992), 21-30. https://doi.org/10.1016/S0022-3093(05)80548-4.

[xlvii] R. Xu, W. Zhang, J. Xu, Z. Tian, F. Deng, X. Han, X. Bao, Multinuclear solidstate NMR studies on the formation mechanism of aluminophosphate molecular sieves in ionic liquids, J. Phys. Chem., 117 (2013), 5848-5854. https://doi.org/10.1021/jp400422z.

[xlviii] B. Peplinski, B. Adamczyk, P. Formanek, C. Meyer, O. Krüger, H. Scharf, S. Reinsch, M. Ostermann, M. Nofz, C. Jäger, C. Adam, F. Emmerling, Nanocrystalline and stacking-disordered $\beta$ cristobalite $\mathrm{AlPO}_{4}$ chemically stabilized at room temperature: synthesis, physical characterization, and X-ray powder diffraction data, ICDD, Volume 32, Issue S1 (2017), S193-S200. https://doi.org/10.1017/S0885715617000537.

[xlix] L.T. Zhuravlev, The surface chemistry of amorphous silica. Zhuravlev model, Colloïds Surf., A, 173 (2000), 1-38. https://doi.org/10.1016/S0927-7757(00)00556-2.

[1] B. Zhang, K. J. D. MacKenzie, I. W. M. Brown, Crystalline phase formation in metakaolinite geopolymers activated with $\mathrm{NaOH}$ and sodium silicate, J Mater Sci. 44 (2009), 4668-4676. http://dx.doi.org/10.1007/s10853-009-3715-1.

[li] J.-L. Guth, Y. Hubert, D. Jordan, A. Kalt, B. Perati, R. Wey, Un nouveau type de silice hydratée cristallisée, de formule $\mathrm{H}_{2} \mathrm{Si}_{3} \mathrm{O}_{7}$, C. R. Acad. Sc. Paris, 285 (1977), $1367-$ 1370.

[lii] P. Deshmukh, J. Bhatt, D. Peshwe, S. Pathak, Determination of Silica Activity Index and XRD, SEM and EDS Studies of Amorphous $\mathrm{SiO}_{2}$ Extracted from Rice Husk Ash, Transactions of the Indian Institute of Metals, 65 (2012), 63-70. https://doi.org/10.1007/s12666-011-0071-z.

[liii] B. Boonchom, S. Kongtaweelert, Study of kinetics and thermodynamics of the dehydration reaction of $\mathrm{AlPO}_{4} \mathrm{H}_{2} \mathrm{O}$, J. Therm. Anal. Calorim., 99 (2010), 531-538. https://doi.org/10.1007/s10973-009-0113-5.

[liv] J. Zarzycki, Les verres et l'état vitreux, Masson, Paris, France, 1982. 